\title{
Reclassification of Xanthomonas
}

\author{
L. VAUTERIN,* B. HOSTE, K. KERSTERS, AND J. SWINGS \\ Laboratorium voor Microbiologie, Universiteit Gent, B-9000 Ghent, Belgium
}

\begin{abstract}
A comprehensive DNA-DNA hybridization study was performed by using 183 strains of the genus Xanthomonas. This genus was shown to comprise 20 DNA homology groups which are considered genomic species. Four groups corresponded to the previously described species Xanthomonas albilineans, Xanthomonas fragariae, Xanthomonas oryzae, and Xanthomonas populi. The previously described species Xanthomonas campestris was heterogeneous and was divided into 16 DNA homology groups. One of these groups exhibited a high level of DNA homology with Xanthomonas axonopodis. The 62 pathovars represented in this study were allocated to appropriate species. Our results, together with previous taxonomic data, supported a comprehensive revision of the classification of the genus Xanthomonas. The species $X$. albilineans, $X$. fragariae, $X$. oryzae, and $X$. populi are not affected. The type species of the genus, $X$. campestris (Pammel 1895) Dowson 1939, is emended to include only the pathovars obtained from crucifers (i.e., $X$. campestris pv. aberrans, $X$. campestris pv. armoraciae, $X$. campestris pv. barbareae, $X$. campestris pv. campestris, $X$. campestris pv. incanae, and $X$. campestris pv. raphani). $X$. axonopodis Starr and Garces 1950 is emended to include 34 former $X$. campestris pathovars. The following species names are proposed: Xanthomonas arboricola sp. nov., including $X$. arboricola pv. corylina, $X$. arboricola pv. juglandis, $X$. arboricola pv. poinsettiicola (type $\mathrm{C}$ strains of the former $X$. campestris pathovar), $X$. arboricola pv. populi, and $X$. arboricola pv. pruni; Xanthomonas bromi sp. nov. for strains isolated from bromegrass; Xanthomonas cassavae (ex Wiehe and Dowson 1953) sp. nov., nom. rev.; Xanthomonas codiaei sp. nov., including type B strains of the former taxon $X$. campestris pv. poinsettiicola; Xanthomonas cucurbitae (ex Bryan 1926) sp. nov., nom. rev.; Xanthomonas hortorum sp. nov., including $X$. hortorum pv. hederae, $X$. hortorum pv. pelargonii, and $X$. hortorum pv. vitians; Xanthomonas hyacinthi (ex Wakker 1883) sp. nov., nom. rev.; Xanthomonas melonis sp. nov.; Xanthomonas pisi (ex Goto and Okabe 1958) sp. nov., nom. rev.; Xanthomonas sacchari sp. nov. for strains isolated from diseased sugarcane in Guadeloupe; Xanthomonas theicola sp. nov.; Xanthomonas translucens (ex Jones, Johnson, and Reddy 1917) sp. nov., nom. rev., including $X$. translucens pv. arrhenatheri, $X$. translucens pv. cerealis, $X$. translucens pv. graminis, $X$. translucens pv. hordei, $X$. translucens pv. phlei, $X$. translucens pv. phleipratensis, $X$. translucens pv. poae, $X$. translucens pv. secalis, $X$. translucens pv. translucens, and $X$. translucens pv. undulosa; Xanthomonas vasicola sp. nov., including $X$. vasicola pv. holcicola and $X$. vasicola pv. vasculorum (type B strains of the former taxon $X$. campestris pv. vasculorum); and Xanthomonas vesicatoria (ex Doidge 1920) sp. nov., nom. rev., which includes the type B strains of the former taxon $X$. campestris pv. vesicatoria. Differentiating characteristics were determined for the new species on the basis of metabolic activity on a range of carbon substrates by using the Biolog GN microplate system.
\end{abstract}

In the past, the taxonomy of bacteria has been dominated by a phenetic approach, and many classification systems have been and still are based on what were thought to be important phenotypic properties. The taxonomy of the genus Xanthomonas has followed this tendency in that a single phenotypic feature, host specificity, has determined the classification of the genus. Since the first report of a xanthomonad (55) until 1974 , it was common practice to define a plant-pathogenic xanthomonad isolated from a new host plant as a new Xanthomonas species. The unreasonable number of nomenspecies resulting from this practice was drastically reduced by Dye and Lelliott (19), who justified their reclassification by referring to the impossibility of differentiating nomenspecies by any feature other than host specificity $(10,17)$. Later, names of former nomenspecies were preserved in a special-purpose classification (18) as Xanthomonas campestris pathovar names.

The original classification of the genus Xanthomonas, in which all of the phytopathological variants of $X$. campestris were recognized as separate species, was not sound taxonomically. With the exception of the ambiguous feature of host specificity, few biochemical and phenotypic characteristics were used to differentiate the species. In the last few years,

\footnotetext{
* Corresponding author. Mailing address: Laboratorium voor Microbiologie, Universiteit Gent, Ledeganckstraat 35, B-9000 Ghent, Belgium.
}

workers have provided evidence that the current classification, in which $X$. campestris contains more than 140 pathovars, is not a reflection of genomic relationships. The first DNA hybridization experiments performed with Xanthomonas nomenspecies were described by Murata and Starr (35), who observed that up to $50 \%$ of the DNA was characteristic for the nomenspecies which they studied. Schroth and Hildebrand (39) have stressed the need for genomic homology matrices to clarify the taxonomic relationships within the genera Pseudomonas and Xanthomonas. Extensive studies based on electrophoresis of proteins (48), gas chromatographic analysis of fatty acid methyl esters (FAME) (60), restriction fragment length polymorphisms of genomic DNA (32), restriction patterns of rRNAs (4), and DNA hybridization $(28,37,49,50)$ have shown that a number of more or less well-defined groups exist in $X$. campestris and that a number of pathovars are heterogeneous. Most of the DNA hybridization results that have been published are fragmentary $(49,50)$ or deal with specific groups, such as pathovars isolated from members of the Poaceae (51) or from citrus (52), and are part of a polyphasic study on the taxonomy of the genus Xanthomonas conducted in our laboratory. A global DNA homology matrix for the genus Xanthomonas should serve as a basis for reclassification of the species and pathovars of the genus $(39,49)$.

A classification system based solely on differences in overall genomic DNAs would in many cases be impractical for diag- 
nostic purposes, especially in laboratories in which phenotypic traits are routinely used for identification. Among the recent developments in bacterial taxonomy are ready-made phenotypic and chemotaxonomic fingerprinting systems which typically yield a large number of discriminating characteristics from a single experiment. Such techniques, combined with objective numerical comparisons and clustering algorithms in which computers are used, have enabled taxonomists to compare many characteristics of large numbers of organisms in a rational and unbiased way. Each of the conditions mentioned above (i.e., availability of fast fingerprinting systems, use of large numbers of strains, and numerical comparison) is very important in modern classification. On the other hand, DNA homology, as expressed by levels of hybridization of total cellular DNAs, remains the ultimate criterion for the circumscription of a bacterial species (56). Ideally, polyphasic taxonomy should be based on data from phenotypic, chemotaxonomic, and genotypic approaches, and classification schemes will be stable and useful only when the results obtained from all of these approaches converge to a reasonable degree.

Attempts have been made by Lee et al. (33) and Hildebrand et al. (27) to study phenotypic traits that differentiate the known genomic groups of the genus Xanthomonas. The commercial GN microplate assay (Biolog, Inc., Hayward, Calif.) was recently evaluated for its ability to identify members of the genus Xanthomonas and other plant-pathogenic bacteria (30), particularly $X$. campestris pv. citri (54) and $X$. campestris pv. vesicatoria (6). GN microplates are designed to fingerprint gram-negative bacteria by using tetrazolium violet as a redox indicator to reveal the metabolic activity of bacteria on 95 different carbon compounds (5). Although in previous studies $(30,54)$ the commercial database led to low percentages of correct identification, it was clearly shown that GN microplates distinguish between xanthomonads and may offer great potential for the identification of these organisms. In this study, a number of representatives of all previously described Xanthomonas genomic groups were characterized and compared by using the GN microplate assay.

In this paper we present and synthesize all of the available DNA homology data for the genus Xanthomonas and propose a new classification of Xanthomonas species in which both the genomic relationships and the needs of plant pathologists for a rational nomenclature are taken into account. Phenotypic data from previous studies and from the Biolog GN microplate fingerprint analysis are used to describe and differentiate the genomic groups.

\section{MATERIALS AND METHODS}

Bacterial strains. All of the strains used in this study were selected on the basis of the results of a fingerprint analysis of more than 1,000 Xanthomonas strains in which sodium dodecyl sulfate-polyacrylamide gel electrophoresis (SDS-PAGE) of proteins was used and on the basis of the results of a FAME analysis, as described previously $(48,49,51,52,60)$. We verified that these organisms were authentic xanthomonads by determining their Xanthomonas-specific protein patterns and fatty acid contents $(48,60)$. A total of 183 strains representing all of the Xanthomonas species and $62 X$. campestris pathovars were compared by performing DNA hybridization experiments. These strains are listed in Table 1 . We used the following 252 strains representing all of the genomic groups described in this study for phenotypic characterization studies performed with Biolog GN microplates: Xanthomonas albilineans LMG 487, LMG 488, LMG 490, LMG 494 ${ }^{\mathrm{T}}$ (T $=$ type strain), and LMG 482; Xanthomonas axonopodis LMG 539, LMG 540 , LMG 538 ${ }^{\mathrm{T}}$, LMG 537, and LMG 541; $X$. campestris LMG 8272 and LMG 8274 (isolated from bromegrass; received as $X$. campestris pv. graminis); $X$. campestris pv. alfalfae LMG $497^{*}\left({ }^{*}=\right.$ pathovar reference strain), LMG 495 , LMG 8018 , LMG 8079, LMG 8080, LMG 8019, and LMG 8020; $X$. campestris pv. arrhenatheri LMG 7384, LMG 588, LMG 727*, LMG 591, and LMG 590; $X$. campestris pv. begoniae LMG 7194, LMG 7196, LMG 7595, LMG 552, and LMG 7303*; $X$. campestris pv. cajani LMG 7473, LMG 7387 , and LMG $558^{*} ; X$. campestris pv. campestris LMG 568 ${ }^{\mathrm{T}}$, LMG 8121, LMG 8003, LMG 8035, LMG 8051, LMG
583, LMG 7514, LMG 7516, LMG 575, LMG 7662, LMG 571, LMG 8001, LMG 8119, LMG 8099, LMG 8112, LMG 8082, LMG 8055, LMG 8123, and LMG 8100; $X$. campestris pv, cassavae type A strains LMG 5246, LMG 5264, LMG 672 , LMG 5270, and LMG 673*; $X$. campestris pv. cerealis LMG 880, LMG 679*, LMG 891, and LMG 887; $X$. campestris pv. citri A LMG 9176, LMG 9669, LMG 9671, LMG 682*, LMG 8657, LMG 9321, and LMG 8650; $X$. campestris pv. citri B LMG 9182, LMG 9183, and LMG 9179; $X$. campestris pv. citri C LMG 8655, LMG 8656, LMG 9181, LMG 9654, and LMG 9658; $X$. campestris pv. citri D LMG 9185; $X$ campestris pv, citri E LMG 9168, LMG 9160, LMG 9174, and LMG 9162; $X$. campestris pv. coracanae LMG $686^{*}$ and LMG $7476 ; X$. campestris pv. cucurbitae LMG 8661, LMG 8662, LMG 7480, LMG 7481, and LMG 690*; $X$. campestris pv. dieffenbachiae LMG 7399, LMG 8664, LMG 7484, LMG 695*, and LMG 7400; $X$. campestris pv. glycines LMG 8027, LMG 8126, LMG 8128, LMG $712^{*}$, and LMG 8026; $X$. campestris pv. graminis LMG $726^{*}$ and LMG 595; $X$. campestris pv. hederae LMG 7414, LMG 7413, LMG 734, LMG 733*, and LMG 8665; $X$. campestris pv. holcicola LMG 7489, LMG 736*, LMG 7416, LMG 8276, and LMG 8277; $X$ campestris pv, hordei LMG 882, LMG 879, LMG 737* LMG 720 , and LMG $884 ; X$. campestris pv. hyacinthi LMG 740, LMG 7419, LMG 742, LMG 739*, and LMG 8042; $X$. campestris pv. juglandis LMG 8045, LMG 751, LMG 8046, LMG $747^{*}$, and LMG 750; $X$. campestris pv. malvacearum LMG 7430, LMG 7427, LMG 764, LMG 762, LMG 761*, and LMG 7427; $X$. campestris pv. manihotis LMG 782, LMG 768, LMG 780, LMG 769, and LMG $773^{*} ; X$. campestris pv. melonis LMG 8671 and LMG $8674 ; X$. campestris pv. pelargonii LMG 7354, LMG 7316, LMG 7715, LMG 7753, LMG 7764, LMG 7708, LMG 7690, LMG 820, LMG 7317, LMG 7318, LMG 7710, LMG 7315, LMG 7321, LMG 7356, LMG 7706, LMG 7763, LMG 7314*, LMG 7312, and LMG 7691; $X$. campestris pv. phaseoli LMG 7455*, LMG 8014, LMG 823, LMG 842, LMG 821, and LMG 829; $X$. campestris pv. phaseoli var. fuscans LMG 7459 , LMG 7456, LMG 825, LMG 837, LMG 841, and LMG 8038; $X$. campestris pv. phlei LMG 730*, LMG 719, LMG 716, and LMG 723; $X$. campestris pv. phleipratensis LMG $843^{*} ; X$. campestris pv. pisi LMG $847 \mathrm{t}^{*}$ and LMG $847 \mathrm{t} 2^{*} ; X$. campestris pv. poae LMG $728^{*} ; X$. campestris pv. poinsettiicola type A strain LMG $849^{*} ; X$. campestris pv. poinsettiicola type B strains LMG 8678 and LMG 8677; $X$. campestris pv, poinsettiicola type C strain LMG $5402 ; X$. campestris pv. pruni LMG 854, LMG 853, LMG 855, LMG 8679, LMG 852*, and LMG 7438; $X$. campestris pv. ricini LMG 7442, LMG 861*, LMG 7443, and LMG 7444; $X$. campestris pv. secalis LMG $883^{*} ; X$. campestris pv. theicola LMG 8686 , LMG $8684^{*}$ and LMG $8685 ; X$ campestris pv, translucens LMG $876^{*}$, LMG 5259 , LMG 5260, LMG 5262, and LMG 875; $X$. campestris pv. undulosa LMG 8283, LMG 885, LMG 888, and LMG 886; $X$. campestris pv. vasculorum type A strains LMG 903, LMG 8285, LMG 901*, LMG 899, and LMG 894; $X$. campestris pv. vasculorum type B strains LMG 896, LMG 8284, LMG 900, and LMG 902; $X$ campestris pv. vesicatoria type A strains LMG 668, LMG 667, LMG 909, LMG 910, LMG 906, LMG 905, LMG 929, LMG 913, LMG 922, LMG 932, and LMG 914; $X$. campestris pv. vesicatoria type B strains LMG 935, LMG 925, LMG 919, LMG 917, LMG 916, LMG 911*, and LMG 920; $X$. campestris pv. vitians type A strain LMG 937* $X$. campestris pv. vitians type B strains LMG 7508, LMG 7510, LMG 8688, LMG 8690, and LMG 8689; Xanthomonas fragariae LMG 706 and LMG 708'; Xanthomonas oryzae pv. oryzae LMG 5047 ${ }^{\mathrm{T}}$, LMG 795, LMG 641, LMG 806, and LMG 803; $X$. oryzae pv, oryzicola LMG 661, LMG 797*, LMG 665, LMG 793, and LMG 657; Xanthomonas populi LMG 970 ${ }^{\mathrm{T}}\left(=\mathrm{LMG} 5743^{\mathrm{T}}\right)$ and LMG 975; and strains LMG 476 and LMG 471 from sugarcane received as $X$. albilineans.

The following abbreviations for culture collections are used in strain designations in this paper: LMG, Laboratorium voor Microbiologie Culture Collection, Universiteit Gent, Ghent, Belgium; NCPPB, National Collection of Plant Pathogenic Bacteria, Harpenden, Hertsfordshire, United Kingdom; ICMP, International Collection of Microorganisms from Plants, Department of Scientific and Industrial Research Mount Albert Research Centre, Auckland, New Zealand ATCC, American Type Culture Collection, Rockville, Md.; DSM, Deutsche Sammlung von Mikroorganismen und Zellkulturen $\mathrm{GmbH}$, Braunschweig, Germany; CFBP, Collection Française de Bactéries Phytopathogènes, Institut National de la Recherche Agronomique, Station de Pathologie Végétale et Phytobactériologie, Angers, France.

DNA hybridization. DNAs were extracted and purified as described by Marmur (34). The levels of DNA binding were determined from the initial renaturation rates by using a spectrophotometer (13). The renaturation rates were determined in $2 \times \mathrm{SSC}$ at the optimal renaturation temperature, $80.8^{\circ} \mathrm{C}$, which was calculated from the G+C contents as described by De Ley (12) $(1 \times \mathrm{SSC}$ is $0.15 \mathrm{M} \mathrm{NaCl}$ plus $0.015 \mathrm{M}$ sodium citrate)

Phenotypic analysis with the Biolog GN microplate system. Stock cultures were subcultured on nutrient agar $(0.1 \%$ [wt/vol] Lab Lemco, $0.2 \%$ [wt/vol] yeast extract, $0.5 \%$ [wt/vol] peptone, $0.5 \%$ [wt/vol] $\mathrm{NaCl}, 2 \%$ [wt/vol] bacteriological agar) for $72 \mathrm{~h}$ at room temperature. A small quantity of cells was streaked onto Trypticase soy agar plates and incubated for $24 \mathrm{~h}$ at $28 \pm 0.5^{\circ} \mathrm{C}$. Since $X$. populi does not grow at $28^{\circ} \mathrm{C}$, strains of this species were incubated at $19 \pm 0.5^{\circ} \mathrm{C}$.

To prepare inocula, sterile cotton sticks were carefully dipped into the colonies, and the cells were suspended in sterile saline. The optical density of each inoculum was determined spectrophotometrically at $590 \mathrm{~nm}$ and was adjusted to 0.190 to 0.210 . The Biolog GN microplates were preincubated at $28^{\circ} \mathrm{C}$ and inoculated with $150 \mu \mathrm{l}$ of suspension per reaction well; they were incubated at 28 $\pm 0.5^{\circ} \mathrm{C}$. 
TABLE 1. DNA homology groups, pathovars and strains analyzed in DNA hybridization experiments, and proposed species names

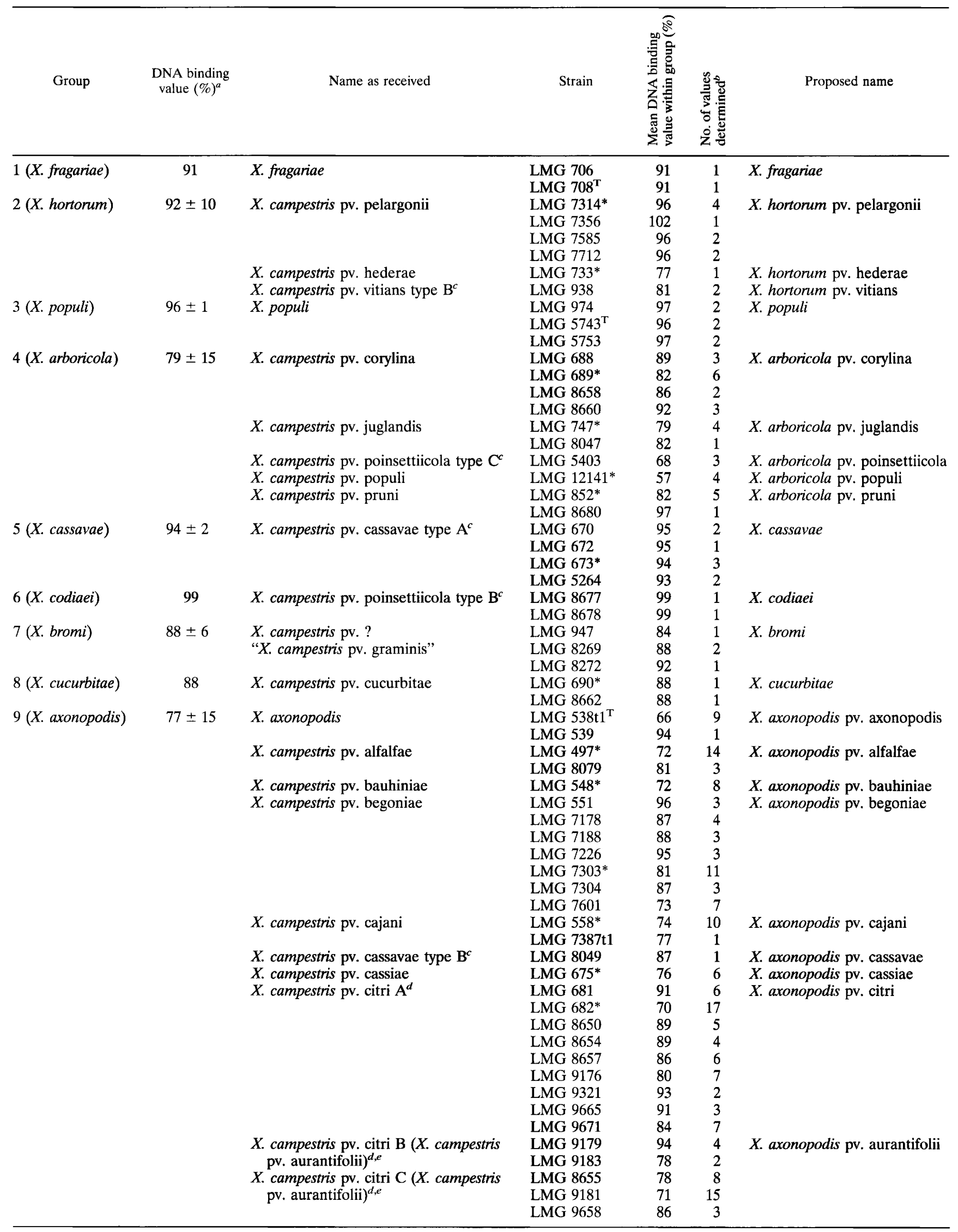


TABLE 1-Continued

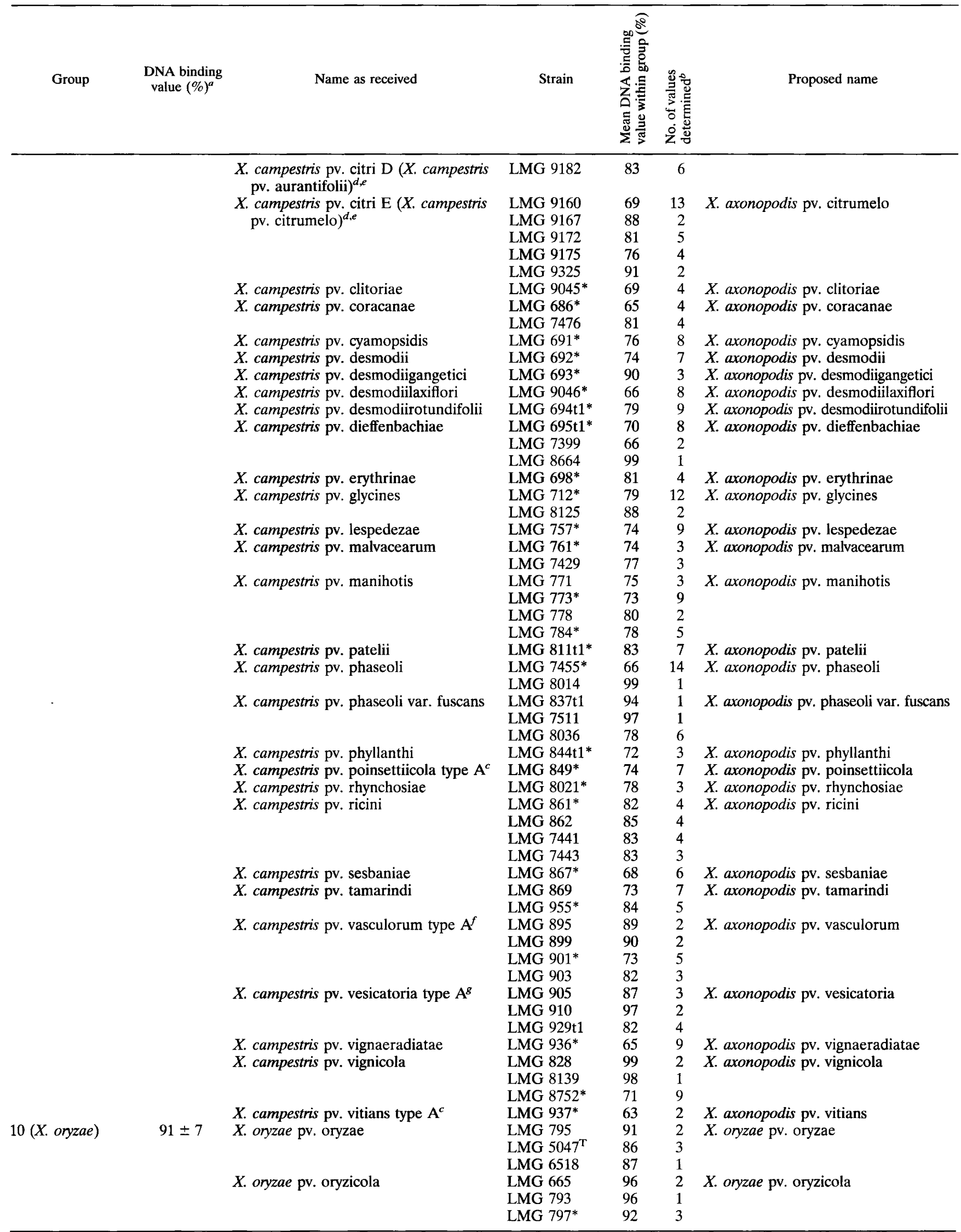


TABLE 1-Continued

\begin{tabular}{|c|c|c|c|c|c|c|}
\hline Group & $\begin{array}{l}\text { DNA binding } \\
\text { value }(\%)^{a}\end{array}$ & Name as received & Strain & 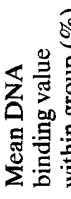 & 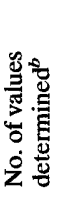 & Proposed name \\
\hline \multirow[t]{6}{*}{$11(X$. vasicola $)$} & $90 \pm 4$ & $X$. campestris pv. holcicola & LMG $736 \mathrm{t} 2 *$ & 92 & 3 & $X$. vasicola pv. holcicola \\
\hline & & & LMG 7416 & 92 & 1 & \\
\hline & & & LMG 7489 & 92 & 2 & \\
\hline & & $X$. campestris pv. vasculorum type $\mathrm{B}^{f}$ & LMG 900 & 89 & 3 & $X$. vasicola pv. vasculorum \\
\hline & & & LMG 902 & 86 & 2 & \\
\hline & & & LMG 8284 & 93 & 1 & \\
\hline $12(X$. pisi $)$ & & $X$. campestris pv. pisi & LMG $847 \mathrm{t} 1^{*}$ & & & $X$. pisi \\
\hline \multirow[t]{2}{*}{13 (X. melonis) } & 88 & $X$ campestris pv. melonis & LMG $8670 t 1^{*}$ & 88 & 1 & $X$. melonis \\
\hline & & & LMG 8672 & 88 & 1 & \\
\hline \multirow[t]{2}{*}{$14(X$. vesicatoria $)$} & 99 & $X$. campestris pv. vesicatoria type $\mathrm{B}^{g}$ & LMG 911t1* & 99 & 1 & $X$. vesicatoria \\
\hline & & & LMG $920 t 1$ & 99 & 1 & \\
\hline \multirow{17}{*}{15 (X. campestris) } & $87 \pm 7$ & $X$. campestris pv. aberrans & LMG $9037^{*}$ & 81 & 4 & $X$. campestris pv. aberrans \\
\hline & & $X$ campestris pv. armoraciae & LMG $535^{*}$ & 86 & 6 & $X$ campestris pv. armoraciae \\
\hline & & & LMG $7383 \mathrm{t} 2$ & 89 & 2 & \\
\hline & & $X$ campestris pv. barbareae & LMG $547^{*}$ & 86 & 7 & $X$. campestris pv. barbareae \\
\hline & & & LMG 7385 & 95 & 2 & \\
\hline & & $X$. campestris pv. campestris & LMG 567 & 96 & 3 & $X$. campestris pv. campestris \\
\hline & & & LMG $568^{T}$ & 90 & 10 & \\
\hline & & & LMG 571 & 89 & 4 & \\
\hline & & & LMG 573 & 87 & 3 & \\
\hline & & & LMG 583 & 87 & 5 & \\
\hline & & & LMG 7514 & 86 & 3 & \\
\hline & & & LMG 8032 & 92 & 2 & \\
\hline & & $X$. campestris pv. incanae & LMG 7421 & 95 & 2 & $X$. campestris pv. incanae \\
\hline & & & LMG $7490^{*}$ & 83 & 6 & \\
\hline & & $X$. campestris pv. raphani & LMG $860 \mathrm{t} 1^{*}$ & 84 & 7 & $X$. campestris pv. raphani \\
\hline & & & LMG 7505 & 86 & 4 & \\
\hline & & & LMG 8134 & 87 & 2 & \\
\hline \multirow[t]{23}{*}{$16(X$. translucens $)$} & $78 \pm 11$ & $X$. campestris pv. arrhenatheri & LMG 588 & 76 & 6 & $X$. translucens pv. arrhenatheri \\
\hline & & & LMG $727 \mathrm{t}^{*}$ & 80 & 3 & \\
\hline & & $X$. campestris pv. cerealis & LMG $679^{*}$ & 67 & 8 & $X$. translucens pv. cerealis \\
\hline & & & LMG 880 & 82 & 1 & \\
\hline & & $X$. campestris pv. graminis & LMG 713 & 88 & 1 & $X$. translucens pv. graminis \\
\hline & & & LMG $726^{*}$ & 75 & 7 & \\
\hline & & $X$. campestris pv. hordei & LMG $737^{*}$ & 77 & 10 & $X$. translucens pv. hordei \\
\hline & & & LMG 879 & 84 & 2 & \\
\hline & & & LMG 882 & 81 & 3 & \\
\hline & & & LMG 8279 & 75 & 1 & \\
\hline & & $X$. campestris pv. phlei & LMG 716 & 85 & 4 & $X$. translucens pv. phlei \\
\hline & & & LMG $730^{*}$ & 97 & 1 & \\
\hline & & $X$ campestris pv. phleipratensis & LMG $843^{*}$ & 72 & 3 & $X$. translucens pv. phleipratensis \\
\hline & & $X$ campestris pv, poae & LMG 594 & 90 & 1 & $X$. translucens pv. poae \\
\hline & & & LMG $728^{*}$ & 78 & 10 & \\
\hline & & $X$. campestris pv. secalis & LMG $883^{*}$ & 77 & 9 & $X$. translucens pv. secalis \\
\hline & & & LMG 7507t1 & 84 & 1 & \\
\hline & & $X$. campestris pv. translucens & LMG $876^{*}$ & 80 & 8 & $X$. translucens pv. translucens \\
\hline & & & LMG 5259 & 69 & 2 & \\
\hline & & & LMG 5260t1 & 90 & 1 & \\
\hline & & $X$. campestris pv. undulosa & LMG 885 & 98 & 1 & $X$. translucens pv. undulosa \\
\hline & & & LMG 888 & 85 & 3 & \\
\hline & & & LMG 892* & 77 & 10 & \\
\hline \multirow{3}{*}{17 (X. hyacinthi) } & $98 \pm 2$ & $X$. campestris pv. hyacinthi & LMG $739^{*}$ & 97 & 2 & $X$. hyacinthi \\
\hline & & & LMG 742 & 99 & 2 & \\
\hline & & & LMG 8041 & 99 & 2 & \\
\hline $18(X$. theicola $)$ & & $X$. campestris pv. theicola & LMG $8684^{*}$ & & & $X$. theicola \\
\hline \multirow{2}{*}{19 (X. sacchari) } & 98 & "X. albilineans" & LMG 471 & 98 & 1 & X. sacchari \\
\hline & & & LMG 476 & 98 & 1 & \\
\hline \multirow{2}{*}{$20(X$. albilineans $)$} & 97 & $X$. albilineans & LMG 482 & 97 & 1 & $X$. albilineans \\
\hline & & & LMG $494^{\mathrm{T}}$ & 97 & 1 & \\
\hline 21 (S. maltophilia) & & S. maltophilia & LMG $958^{\mathrm{T}}$ & & & S. maltophilia \\
\hline
\end{tabular}

${ }^{a}$ Mean \pm standard deviation DNA binding value for the group.

${ }^{b}$ Number of DNA hybridization values determined for a strain within the group.

${ }^{c}$ Genomic types of the same pathovar as determined in this study.

${ }^{d}$ Groups defined by Hartung and Civerolo (24).

${ }^{e}$ The pathovar names in parentheses are pathovar names proposed by Gabriel et al. (22).

$f$ Types defined by Vauterin et al. (51).

$g$ Types defined by Vauterin et al. (49). 


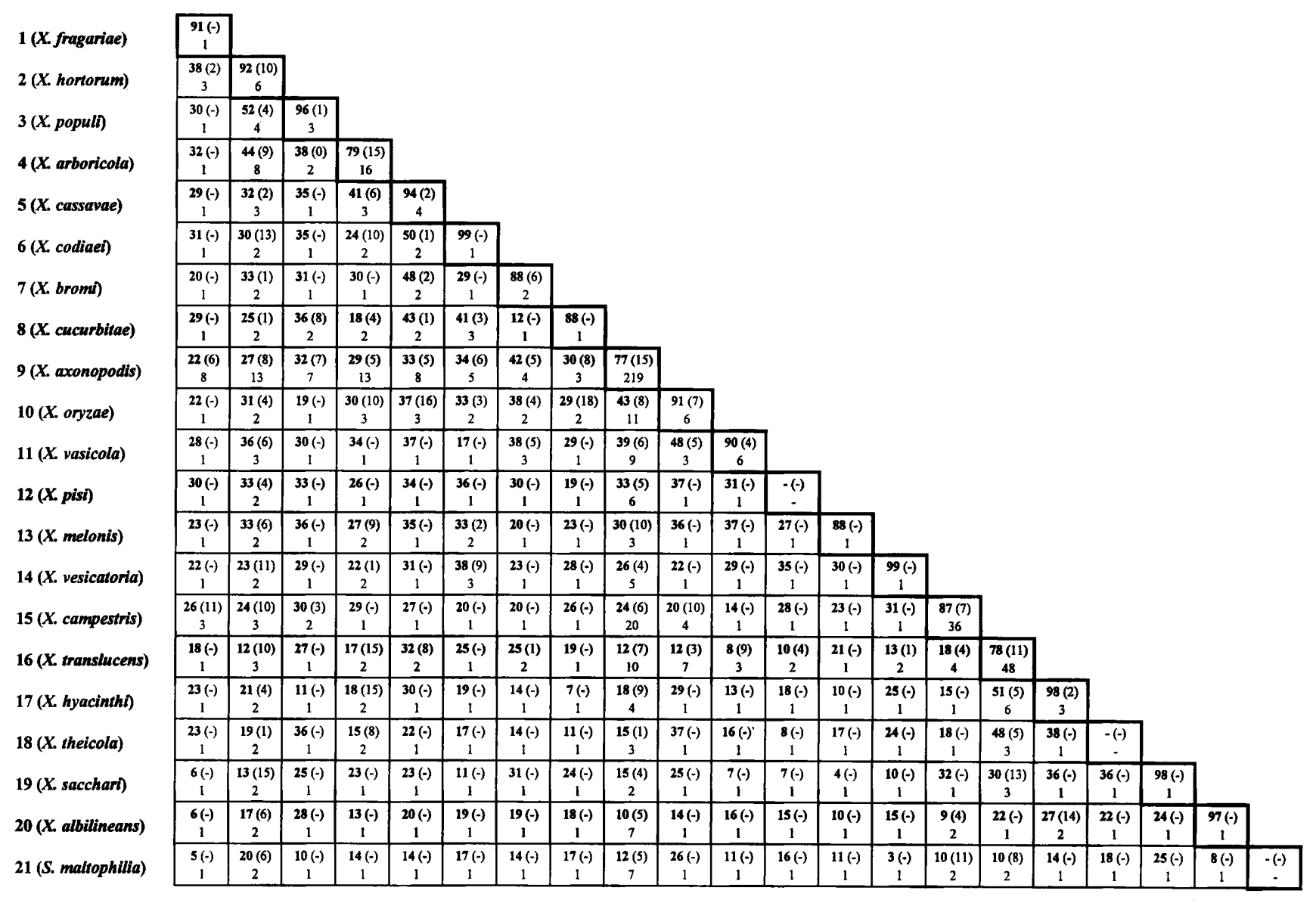

FIG. 1. Average DNA binding values within and between 20 Xanthomonas DNA homology groups and $S$. maltophilia. The standard deviations are indicated in parentheses, and the numbers of values determined are indicated below the DNA binding values.

Visual observations were made after 24,48 , and $72 \mathrm{~h}$. The color reactions were recorded as positive or negative. A dedicated computer program, BIONUM, was written on an IBM-PC (46a) and was used to compare and cluster the strains on the basis of different similarity coefficients for binary data and on the basis of average linkage clustering data. The BIONUM program was also used for a statistical analysis which was based on the groups revealed by DNA hybridization.

\section{RESULTS AND DISCUSSION}

DNA hybridization. A total of 790 DNA hybridization values were determined for 183 strains. All of the values presented below are the averages of the values from at least two independent measurements. The overall experimental error of the method was $\pm 5.8 \%$ DNA binding, as determined from the standard deviations of the replications. Since the complete matrix of DNA homology values was too large and uninformative in its original form, strains which exhibited average homology values (DNA binding values) of at least $60 \%$ were grouped together. This resulted in 20 genomic groups (groups 1 through 20) and a separate group (group 21) for the type strain of Stenotrophomonas maltophilia Palleroni and Bradbury 1993 (36) (formerly Xanthomonas maltophilia Swings, De Vos, Van den Mooter, and De Ley 1983 [42]). Since our preliminary description of six DNA homology groups in the genus Xanthomonas (49), a number of additional groups have been identified. In order to present the genomic groups in a natural sequence, they were ordered and numbered on the basis of their levels of relatedness. The strains which we studied and the DNA homology groups to which they are assigned are shown in Table 1, which also shows the average level of internal homogeneity and the corresponding standard deviation calculated for each group. For each strain, the average level of DNA binding with the other members of the group to which it belongs and the number of hybridization values determined are indicated. As discussed below, a number of $X$. campestris pathovars were composed of two or more unrelated genotypes, which were designated type A, type B, etc.

A matrix was generated from the DNA homology group data, and this matrix shows the average DNA binding values within and between groups along with the corresponding standard deviations and the numbers of hybridization values determined (Fig. 1).

DNA homology groups and their significance. In general, the levels of DNA binding for strains belonging to the same group were high, ranging from 80 to $100 \%$. The average levels of DNA binding between strains belonging to different Xanthomonas DNA homology groups (Fig. 1) were generally low; typically, the levels of DNA homology were less than $40 \%$. Higher levels of homology, about $50 \%$, were found between groups 2 and 3, between groups 5 and 6 , between groups 5 and 7 , and between group 10 and groups $11,16,17$, and 18 . These findings led to the hypothesis that two major classes of DNA homology could be differentiated in the genus Xanthomonas, a class of genomically almost unrelated strains and a class of genomically highly related strains exhibiting levels of DNA 


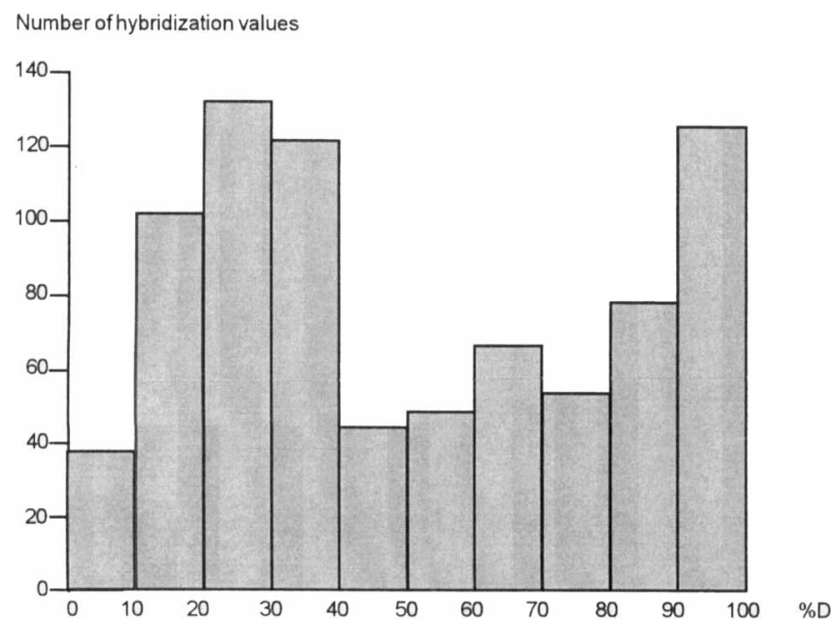

FIG. 2. Distribution of 790 DNA homology values determined for 183 strains of the genus Xanthomonas. \% D, DNA binding value.

homology of more than $80 \%$. To verify this hypothesis, all 790 hybridization values were divided into classes of $10 \%$, a value which was chosen because it was significantly larger than the overall error of the method $(5.8 \%)$. These classes were used to construct a bar graph (Fig. 2), and this graph showed that there were two clear maxima, at 20 to $30 \%$ and at 90 to $100 \%$. A third less pronounced maximum occurred at 60 to $70 \%$; as discussed below, this peak could be explained by the presence of several subgroups in major homology groups 9 and 16. A significant minimum occurred between 40 and $60 \%$ on the frequency graph, which is consistent with the definition of genomic groups at an internal homology value of $60 \%$ (49), as maintained in this study.

Among the 20 Xanthomonas DNA homology groups, group 1 represented $X$. fragariae; the DNA binding value for two strains of this organism was $91 \%$. This species is known to be phenotypically homogeneous and distinct from the other xanthomonads (46).

Group 2 was a very homogeneous group (DNA binding value, 92\%) and included $X$. campestris pv. pelargonii, $X$. campestris pv. hederae, and $X$. campestris pv. vitians type B. $X$. campestris pv. vitians type B contained most of the strains which we studied but did not contain the pathovar reference strain. This heterogeneity was observed previously in a comparative protein electrophoresis study of $X$. campestris pathovars (48).

Group 3 corresponded to the species $X$. populi; the DNA binding value for three strains of this species was $96 \% . X$. populi has been shown to differ from other xanthomonads in a number of phenotypic features (46).

In group $4, X$. campestris pv. corylina, $X$. campestris pv. juglandis, and $X$. campestris pv. pruni were all highly related (average DNA homology value, 89\%). Quinate metabolism was found to be a characteristic that distinguishes these pathovars from strains belonging to most of the other DNA homology groups (33). $X$. campestris pv. populi and $X$. campestris pv. poinsettiicola type $\mathrm{C}$ were related to the other group 4 pathovars at average DNA homology values of 57 and $74 \%$, respectively. However, the individual DNA homology values with other group 4 strains ranged from 48 to $76 \%$.

Group 5 contained most of the $X$. campestris pv. cassavae strains (DNA binding value, 94\%). The exceptions were three isolates obtained from Niger (unpublished data); one of these isolates was used for DNA hybridization experiments and fell into group 9. The authentic $X$. campestris pv. cassavae strains, including the pathovar reference strain, were assigned to type $A$, whereas the isolates obtained from Niger were designated type B strains. $X$. campestris pv. cassavae was previously shown to be distinct from other xanthomonads on the basis of the results of SDS-PAGE of proteins (48).

Two strains received as $X$. campestris pv. poinsettiicola, which were designated type $B$ strains and were isolated from Codiaeum variegatum, were not related to the other $X$. campestris pv. poinsettiicola strains and belonged to a separate DNA homology group, group 6 . These strains were previously shown to be very similar to each other and to differ from other $X$. campestris pv. poinsettiicola strains on the basis of the results of SDS-PAGE of proteins (48).

Strains isolated from Bromus spp. in different countries and received as $X$. campestris pv. graminis or as $X$. campestris strains not allocated to any pathovar were not related to any other pathovar isolated from members of the Poaceae but clustered together in a separate, homogeneous DNA homology group, group 7 , at a DNA binding value of $88 \%$. This confirmed previous results obtained in a comparative study of pathovars isolated from members of the Poaceae (51).

Group 8 included $X$. campestris pv. cucurbitae strains that were related at a DNA binding value of $88 \%$. This pathovar could also be distinguished from other xanthomonads on the basis of the results of SDS-PAGE of proteins (48).

Group 9 was the largest and most heterogeneous Xanthomonas genomic group identified. This group contained $34 X$. campestris pathovars and $X$. axonopodis, and all of the strains were related at an average level of homology of $77 \%$. It has been reported previously (48) that many of the pathovars in group 9, particularly those isolated from members of the Fabaceae, are related on the basis of their SDS-PAGE protein profiles. Within group 9, many strains or subgroups were related to each other at degrees of binding ranging from 60 to $70 \%$. This group was mainly responsible for the peak at 60 to $70 \%$ on the graph showing the distribution of DNA hybridization values (Fig. 2). Within group $9, X$. campestris pv. citri is an example of a taxon containing strains belonging to different subgroups that can be delineated at DNA binding values of 60 to $70 \%(20,52)$. Considered separately, these subgroups correlated well with the pathogenicities of the strains (i.e., group $\mathrm{A}$, the cluster of groups $\mathrm{B}, \mathrm{C}$, and $\mathrm{D}$, and group $\mathrm{E}$ in $X$. campestris pv. citri) $(21,24,25)$. However, other $X$. campestris pathovars were related at very high levels of DNA homology to some of these groups. $X$. campestris pv. glycines and $X$. campestris pv. cajani were related at levels of more than $90 \%$ to pathogenicity group A of $X$. campestris pv. citri, whereas $X$. campestris pv. alfalfae exhibited more than $82 \%$ DNA homology with group E strains (data from the original homology matrix not shown). $X$. campestris pv. dieffenbachiae was shown previously to consist of two types on the basis of SDS-PAGE protein profiles (48). These types contained strains isolated from Anthurium species in Brazil and Dieffenbachia species in the United States. Although both types fell into the same DNA homology group, their level of DNA homology was $66 \%$ (data not shown), which confirmed the previous findings. The same types were also described by Berthier et al. (4) on the basis of rRNA gene restriction patterns. These types may represent different pathovars within the same genomic group. $X$. campestris pv. vasculorum has been subdivided previously into two types, types A and B (51). $X$. axonopodis and $X$. campestris pv. vasculorum type $A$ were highly related to each other and distinct from other xanthomonads associated with members of the Poaceae (51). Both of these taxa were assigned to group 9 on the basis of an overall level of DNA homology of $58 \%$ with 
other strains belonging to group 9, although individual values ranged from 47 to $71 \%$.

Group 10 was represented by $X$. oryzae pv. oryzae and $X$. oryzae pv. oryzicola. The species $X$. oryzae was recently revived by Swings et al. (43) on the basis of phenotypic characteristics and DNA hybridization data. Its separate position in the homology matrix supports this reclassification.

Group 11 was composed of $X$. campestris pv. holcicola and the type B strains of $X$. campestris pv. vasculorum, which were defined at a DNA binding level of $90 \%$. This confirmed previous results based on SDS-PAGE of proteins, FAME analysis, and DNA hybridization (48).

Group 12 was defined by one strain, the pathovar reference strain of $X$. campestris pv. pisi. In terms of relatedness at the species level, this strain exhibited low levels of DNA homology with all of the other groups studied. Vauterin et al. showed that this strain could be distinguished by protein electrophoresis data (48). It has been subdivided into two stable types on the basis of colony morphology, and these types are indistinguishable phenotypically and genotypically.

Group 13 was composed only of $X$. campestris pv. melonis strains, which exhibited a distinct, homogeneous genotype.

Group 14 contained the type B strains of $X$. campestris pv. vesicatoria. Vauterin et al. (49) reported that this pathovar is composed of two unrelated genotypes, which were designated types A and B. These types were later confirmed by protein electrophoresis data (48). The pathovar reference strain is a type B strain, which was shown in this study to belong to a separate Xanthomonas homology group.

In group 15, all of the pathovars isolated from crucifers (members of the family Brassicaceae) are related at a level of DNA binding of $87 \%$. The striking homogeneity of this group of pathovars has been shown previously by FAME fingerprinting (60) and protein electrophoresis (unpublished data).

Ten pathovars isolated from members of the Poaceae were related at a level of $78 \%$ and were placed in group 16. This DNA homology group has been studied in detail by Vauterin et al. (51).

Group 17 was a very homogeneous group with a distinct genotype, and contained $X$. campestris pv. hyacinthi strains. This group is also distinct and homogeneous on the basis of the SDS-PAGE protein profiles of the strains (48).

Group 18 was represented by $X$. campestris pv. theicola and is another distinct group as determined by both DNA hybridization and protein electrophoresis (48).

Group 19 contained strains from Guadeloupe which were received as $X$. albilineans but were members of a different homology group belonging to the genus Xanthomonas. These strains have been discussed in detail previously and have been shown to have distinct protein and FAME profiles (51).

The original $X$. albilineans strains constituted group 20. The characteristics and homogeneity of this species were studied in detail by Yang et al. (59).

The type strain of $S$. maltophilia in group 21 exhibited levels of DNA binding of less than $25 \%$ with members of all of the Xanthomonas DNA homology groups.

Correlation between genomic groups and pathogenic specialization. In an attempt to relate the DNA homology groups to the phytopathogenic specialization of the strains, we found two clear cases in which pathovars that attack related hosts belong to the same genomic group. The first example involved the six pathovars obtained from crucifers (members of the family Brassicaceae), $X$. campestris pv. campestris, $X$. campestris pv. aberrans, $X$. campestris pv. armoraciae, $X$. campestris pv. barbareae, $X$. campestris pv. incanae, and $X$. campestris pv. raphani, which constituted group 15 . Group 15 was defined at a DNA binding value of $87 \%$ and exhibited low levels of DNA homology with all of the other groups. The second example involved pathovars which were obtained from grasses and cereals (members of the family Poaceae) and belonged to group 16 (51). Group 16 included $X$. campestris pv. arrhenatheri, $X$. campestris pv. cerealis, $X$. campestris pv. graminis, $X$. campestris pv. hordei, $X$. campestris pv. phlei, $X$. campestris pv. phleipratensis, $X$. campestris pv. poae, $X$. campestris pv. secalis, $X$. campestris pv. translucens, and $X$. campestris pv. undulosa. Only the following three known $X$. campestris pathovars isolated from members of the Poaceae did not belong to group 16: $X$. campestris pv. coracanae, $X$. campestris pv. holcicola, and $X$. campestris pv. vasculorum. It is also interesting that of the 21 pathovars obtained from legumes (members of the family Fabaceae), only $X$. campestris pv. pisi did not belong to group 9 . However, group 9 is a heterogeneous group which includes pathovars obtained from nonleguminous hosts, such as $X$. campestris pv. citri, $X$. campestris pv. manihotis, $X$. campestris pv. begoniae, $X$. campestris pv. malvacearum, and the species $X$. axonopodis, which were isolated from various hosts.

In group 4 , the genomic relatedness of $X$. campestris $\mathrm{pv}$. corylina, $X$. campestris pv. juglandis, and $X$. campestris pv. pruni can be correlated with the infection mechanism rather than with the botanical relatedness of the host plants. These three pathovars, which were related at a level of $89 \%$, attack hazelnuts, walnuts, and stone fruits, respectively, which are all trees which grow in temperate regions. The very high level of genomic relatedness of these organisms suggests that they may have originated from the same organism, an organism which had the ability to infect and colonize trees in temperate regions.

Examples of the opposite situation, where $X$. campestris pathovars pathogenic for closely related hosts or even the same host occurred in different DNA homology groups, were also found. $X$. campestris pv. cassavae type A and $X$. campestris pv. manihotis (44) are members of groups 5 and 9, respectively. $X$. campestris pv. coracanae, $X$. campestris pv. vasculorum, and $X$. campestris pv. holcicola do not belong to group 16 , which includes all other pathogens of members of the Poaceae (51). $X$. campestris pv. cucurbitae in group 8 and $X$. campestris pv. melonis in group 13 are both pathogenic for members of the family Cucurbitaceae and have overlapping host ranges $(8$, 26).

Strains that had different origins grouped together in group 9, which contained $21 X$. campestris pathovars obtained from members of the Fabaceae and 13 pathovars obtained from other hosts. Furthermore, $X$. campestris pv. pelargonii, $X$. campestris pv. vitians $\mathrm{B}$, and $X$. campestris pv. hederae, which are associated with three different plant families, grouped together in group 2.

Homogeneity and heterogeneity of $X$. campestris pathovars. Most of the $X$. campestris pathovars which we studied were phenotypically and genotypically homogeneous. However, our data revealed that a number of pathovars are composed of two or more unrelated genotypes, which were designated type A, type B, etc. Unless indicated otherwise, type A contained the pathovar reference strain. $X$. campestris pv. vesicatoria consisted of two unrelated types, types $\mathrm{A}$ and $\mathrm{B}$, confirming previous DNA hybridization data (49) and data obtained from SDS-PAGE of cellular proteins (48). Type A fell into DNA homology group 9 , whereas type $B$, containing the pathovar reference strain, fell into a different DNA homology group, group 14. Both groups have been characterized by diverse genotypic (40) and phenotypic methods (6). Similarly, $X$. campestris pv. vasculorum consisted of types A and B (51). 
Type A belonged to DNA homology group 9, whereas type B was related to $X$. campestris pv. holcicola in group 11 . The most heterogeneous pathovar studied was $X$. campestris pv. poinsettiicola, which was composed of types A, B, and C. Type A occurred in group 9, whereas type $C$ was related to the pathogens of trees in group 4. Type B strains constituted a separate DNA homology group, group 6. Most $X$. campestris pv. cassavae strains (type A) formed a homogeneous group; the exceptions were strains obtained from Niger (type B), which produced a characteristic brown soluble pigment in GYCA medium. A special case of a heterogeneous pathovar was represented by $X$. campestris pv. vitians. As shown previously (48, 60 ), most strains of this pathovar are similar; the exception is the aberrant pathovar reference strain, strain LMG 937. The authentic $X$. campestris pv. vitians strains (designated type B) fell into DNA group 2, whereas the pathovar reference strain belonged to group 9. A number of strains isolated from bromegrass in New Zealand and France, which were received as $X$. campestris pv. graminis (51), were not related to $X$. campestris pv. graminis but belonged to a separate DNA homology group, group 7.

Phenotypic analysis of the genomic groups. When we used an incubation time of $24 \mathrm{~h}$ as recommended by the manufacturer of the GN microplates, we found that the color reactions were often not sufficiently developed to allow accurate readings. This was particularly true for some slowly growing species and pathovars, such as $X$. fragariae, $X$. populi, $X$. oryzae pv. oryzae, $X$. campestris pv. hyacinthi, and $X$. campestris pv. theicola. In addition, a level of reproducibility which was unacceptably low for our purposes was obtained when fingerprints of duplicate incubation mixtures were compared. The color reactions were generally much better developed, easier to read, and hence more reliable after $48 \mathrm{~h}$. Readings obtained after $72 \mathrm{~h}$ were very similar to those obtained after $48 \mathrm{~h}$. For these reasons we decided to use the data obtained after $48 \mathrm{~h}$ of incubation in this study.

The level of reproducibility of the procedure which we used was estimated by culturing and inoculating 10 strains in duplicate. In this study the duplicate strains exhibited an average level of reproducibility of $94 \%$ after $48 \mathrm{~h}$ of incubation.

In an attempt to characterize the genomic groups in the genus Xanthomonas phenotypically, the percentages of positive reactions were calculated for all of the substrates for the strains belonging to each group. This resulted in the values shown in Table 2, which lists the average levels of metabolic activity observed with 95 carbon sources for each genomic group. The values in Table 2 are based on a sample of 252 strains. For example, for groups 1, 3, 6, 7, 12, 13, and 19 the average values were based on only two profiles. However, either these groups were known to be very homogeneous as determined by both their SDS-PAGE protein patterns (48; unpublished data) and their FAME profiles (60) or only a few strains were available. An exceptional species in this respect was Xanthomonas pisi; only two distinct colony types of one strain of this species were available. The number of strains used for each species is listed in Table 3.

It is obvious that some DNA homology groups were more homogeneous than others and hence were more accurately defined. In order to get an idea of the consistency of the profiles within each of the groups, the average level of internal homogeneity $(h)$ was calculated by using the following formula:

$$
h=2 \sum_{i=1}^{95} \frac{\left|0.5-x_{m, i}\right|}{95}
$$

where

$$
x_{m, i}=\sum_{j=1}^{n} \frac{x_{i j}}{n}
$$

where $x_{i j}$ is the $i$ th reaction of strain $j$ and $n$ is the total number of strains tested in the group. The $h$ value is 1 if a group is perfectly consistent (i.e., if all of the strains exhibit the same reaction with each carbon substrate) and zero if $50 \%$ of the strains are positive for each substrate. The resulting values are shown in Table 3. Among the least consistent or most variable groups were group 3 , group 7 , and particularly group 9 . Group 3 (X. populi) strains exhibited poor color reactions after $48 \mathrm{~h}$. Ambiguous readings rather than differences in substrate utilization may have been responsible for the apparent heterogeneity of this species. The heterogeneity found for group 9 was based on a total of 99 strains and reliably reflects the genomic diversity of this group.

Tests which differentiated two genomic groups were defined as those tests which yielded at least $90 \%$ positive reactions in one group and less than $10 \%$ positive reactions in the other group. By using this definition, an estimate of the "unicity" of each DNA homology group was calculated by determining the total number of species from which the group could be differentiated by at least one test when the $90 \%$ discrimination level was used as described above. The resulting values are shown in Table 3 and indicate that by using the Biolog GN microplate system we were able to differentiate most of the Xanthomonas genomic groups from one another. However, as the results which we obtained were based on sampling, the results could certainly change slightly for some characters if more strains were added to each of the groups. Identification criteria that unambiguously distinguish the 20 Xanthomonas genomic groups may not exist. It has been pointed out by using Xanthomonas strains as examples that attempts to divide biological populations into clear taxa is inconsistent with the real biological space, which harbors a continuum of cloudy condensed nodes rather than discrete taxa (47), and therefore it may be impossible to provide keys to unambiguously identify such taxa. Nevertheless, we believe that our results illustrate that the Biolog GN microplate system is a sensitive technique for differentiating the plant-pathogenic xanthomonads and that it is a useful tool for helping locate unknown xanthomonads in the new genomic classification.

It is obvious from Tables 2 and 3 that some groups are identified more reliably than others. There are a number of distinguishing tests that can be used for groups such as group 12 (X. campestris pv. pisi), group 19 (Guadeloupe strains obtained from sugarcane), and group 20 (X. albilineans), whereas other groups, such as groups $9,11,14$, and 16 are less wellcharacterized. However, when the average data in Table 2 are used for identification, many reactions that do not fulfill the $90 \%$ discrimination criterion can also be useful for identifying unknown strains. The best identification is certainly obtained when whole fingerprints are compared.

Other interesting features include the carbon compounds which are positive or negative for all or most xanthomonads. These compounds may be descriptive for the genus. Features which were either positive or negative for more than $90 \%$ of the strains and at the same time did not differentiate any of the 20 species were considered characteristic for the genus. The average reactions for Xanthomonas strains are shown in Fig. 3 , and the determinative characteristics are indicated. Reactions which were negative or positive for at least $90 \%$ of the strains but did not distinguish any of the groups are also indicated. 
TABLE 2. Average metabolic activities of the 20 Xanthomonas DNA homology groups on 95 carbon sources in the Biolog GN microplate assay

\begin{tabular}{|c|c|c|c|c|c|c|c|c|c|c|c|c|c|c|c|c|c|c|c|c|c|}
\hline \multicolumn{2}{|r|}{ Carbon substrate } & \multicolumn{20}{|c|}{$\%$ of positive strains in DNA homology group: } \\
\hline $\begin{array}{l}\text { Desig- } \\
\text { nation }\end{array}$ & Name & 1 & 2 & 3 & 4 & 5 & 6 & 7 & 8 & 9 & 10 & 11 & 12 & 13 & 14 & 15 & 16 & 17 & 18 & 19 & 20 \\
\hline A2 & $\alpha$-Cyclodextrin & 0 & 3 & 0 & 0 & $\mathbf{0}$ & 0 & 0 & 0 & 8 & 0 & 0 & 0 & 0 & 0 & 0 & 3 & 20 & 67 & 0 & \\
\hline A3 & Dextrin & 100 & 83 & 100 & 100 & 80 & 100 & 100 & 100 & 90 & 100 & 89 & 100 & 100 & 100 & 100 & 94 & 100 & 100 & 100 & \\
\hline A4 & Glycogen & 100 & 38 & 100 & 92 & 80 & 100 & 50 & 100 & 82 & 70 & 78 & 100 & 100 & 57 & 89 & 78 & 100 & 100 & 100 & 0 \\
\hline A5 & Tween 40 & 0 & 21 & 0 & 75 & 80 & 100 & 50 & 60 & 68 & 30 & 22 & 100 & 100 & 71 & 84 & 38 & 20 & 100 & 100 & 20 \\
\hline A6 & Tween 80 & 0 & 66 & 0 & 92 & 80 & 100 & 50 & 80 & 77 & 40 & 44 & 100 & 100 & 100 & 79 & 50 & 20 & 100 & 100 & 0 \\
\hline A7 & $\begin{array}{l}N \text {-Acetyl-D- } \\
\text { galactosamine }\end{array}$ & 0 & 0 & 0 & 0 & 20 & 0 & 0 & 0 & 12 & 0 & 0 & 100 & 0 & 14 & 0 & 3 & 0 & 0 & 0 & 0 \\
\hline A8 & $N$-Acetyl-D-glucosamine & 50 & 69 & 50 & 100 & 80 & 100 & 100 & 20 & 69 & 40 & 33 & 100 & 100 & 86 & 95 & 78 & 80 & 0 & 100 & 100 \\
\hline A9 & Adonitol & 0 & 0 & 0 & 0 & 0 & 0 & 50 & 0 & 5 & 0 & 0 & 0 & 0 & 0 & 0 & 0 & 0 & 33 & 0 & 0 \\
\hline A10 & L-Arabinose & 0 & 7 & 0 & 8 & 40 & 0 & 50 & 0 & 15 & 20 & 0 & 100 & 0 & 0 & 0 & 41 & 20 & 67 & 100 & 20 \\
\hline A11 & D-Arabitol & 0 & 3 & 0 & 0 & 0 & 0 & 50 & 0 & 6 & 0 & 0 & 0 & 0 & 0 & 0 & 0 & 0 & 0 & 50 & . \\
\hline A12 & Cellobiose & 0 & 97 & 0 & 100 & 80 & 100 & 100 & 100 & 93 & 90 & 89 & 100 & 100 & 86 & 100 & 78 & 100 & 100 & 100 & 60 \\
\hline B1 & meso-Erythritol & 0 & 0 & 0 & 0 & 0 & 0 & 0 & 0 & 0 & 0 & 0 & 0 & 0 & 0 & 0 & 0 & 0 & 0 & 0 & 0 \\
\hline B2 & D-Fructose & 100 & 100 & 100 & 100 & 100 & 100 & 100 & 100 & 98 & 100 & 100 & 100 & 100 & 100 & 100 & 100 & 100 & 100 & 100 & 100 \\
\hline B3 & L-Fucose & 50 & 86 & 0 & 92 & 100 & 0 & 50 & 60 & 84 & 30 & 78 & 100 & 100 & 100 & 89 & 31 & 0 & 100 & 100 & 80 \\
\hline B4 & D-Gala & 50 & 72 & 50 & 100 & 60 & 100 & 100 & 40 & 87 & 40 & 56 & 100 & 100 & 0 & 95 & 47 & 100 & 100 & 100 & 0 \\
\hline B5 & Gentiobiose & 100 & 100 & 50 & 92 & 100 & 100 & 100 & 0 & 91 & 70 & 89 & 100 & 100 & 100 & 100 & 62 & 100 & 100 & 100 & 0 \\
\hline B6 & $\alpha$-D-Glucose & 100 & 100 & 100 & 100 & 100 & 100 & 100 & 100 & 98 & 100 & 89 & 100 & 100 & 100 & 100 & 100 & 100 & 100 & 100 & 100 \\
\hline B7 & meso-Inositol & 0 & 0 & 0 & 0 & 0 & 0 & 0 & 0 & 3 & 0 & 0 & 0 & 0 & 14 & 0 & 3 & 0 & 0 & 0 & 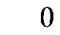 \\
\hline B8 & $\alpha-D-L$ & 0 & 0 & 0 & 42 & 0 & 100 & 50 & 0 & 14 & 0 & 0 & 100 & 50 & 0 & 0 & 3 & 0 & 0 & 100 & $\mathbf{0}$ \\
\hline B9 & Lactul & 0 & 69 & 0 & 67 & 20 & 100 & 50 & 0 & 65 & 0 & 11 & 100 & 100 & 71 & 89 & 28 & 0 & 0 & 100 & 0 \\
\hline B10 & Maltose & 100 & 97 & 100 & 100 & 100 & 100 & 100 & 100 & 94 & 100 & 89 & 100 & 100 & 100 & 100 & 100 & 100 & 100 & 100 & 0 \\
\hline B11 & D-Ma & 0 & 0 & 50 & 0 & 0 & 50 & 50 & 0 & 12 & 0 & 11 & 100 & 0 & 14 & 0 & 0 & 0 & 0 & 50 & 0 \\
\hline B12 & D-Mar & 100 & 100 & 100 & 100 & 100 & 100 & 100 & 100 & 94 & 90 & 89 & 100 & 100 & 86 & 95 & 100 & 100 & 100 & 100 & 100 \\
\hline $\mathrm{C} 1$ & D-Mel & 0 & 97 & 0 & 83 & 100 & 100 & 50 & 80 & 72 & 0 & 0 & 100 & 100 & 86 & 100 & 3 & 0 & 0 & 100 & 0 \\
\hline $\mathrm{C} 2$ & $\beta-\mathrm{Me}$ & 0 & 3 & 50 & 0 & 0 & 100 & 50 & 0 & 9 & 0 & 0 & 100 & 50 & 0 & 0 & 3 & 20 & 0 & 100 & 0 \\
\hline C3 & D-Psi & 100 & 97 & 100 & 100 & 80 & 100 & 100 & 100 & 91 & 90 & 100 & 100 & 100 & 100 & 95 & 97 & 100 & 100 & 100 & 0 \\
\hline C4 & $\mathrm{D}-\mathrm{Raf}$ & 0 & 31 & 0 & 0 & 0 & 50 & 0 & 0 & 37 & 0 & 11 & 100 & 50 & 0 & 53 & 0 & 0 & 0 & 0 & 0 \\
\hline C5 & L-Rha & 0 & 0 & 0 & 0 & 0 & 0 & 50 & 0 & 8 & 0 & 0 & 100 & 0 & 14 & 0 & 0 & 0 & 33 & 0 & 0 \\
\hline C6 & D & 0 & 10 & 50 & 33 & 0 & 50 & 50 & 0 & 28 & 10 & 0 & 100 & 0 & 14 & 0 & 3 & 0 & 33 & 0 & 0 \\
\hline C7 & Sucro & 50 & 79 & 100 & 75 & 20 & 100 & 100 & 0 & 82 & 70 & 22 & 100 & 100 & 43 & 58 & 47 & 100 & 0 & 100 & 100 \\
\hline $\mathrm{C} 8$ & D-Trehalose & 100 & 100 & 100 & 100 & 100 & 100 & 100 & 100 & 98 & 100 & 89 & 100 & 100 & 100 & 100 & 100 & 100 & 67 & 100 & 0 \\
\hline $\mathrm{C} 9$ & $\mathrm{~T}$ & 50 & 24 & 50 & 58 & 40 & 100 & 100 & 0 & 51 & 40 & 33 & 100 & 50 & 29 & 26 & 41 & 80 & 67 & 100 & 0 \\
\hline $\mathrm{C} 10$ & Xylito & 0 & 0 & 0 & 0 & 0 & 0 & 0 & 0 & 2 & 0 & 0 & 0 & 0 & 0 & 0 & 0 & 0 & 0 & 0 & 0 \\
\hline $\mathrm{C} 11$ & Methylp & 100 & 100 & 50 & 100 & 100 & 100 & 100 & 100 & 99 & 100 & 100 & 100 & 100 & 100 & 100 & 100 & 100 & 100 & 100 & 100 \\
\hline $\mathrm{C} 12$ & Mon & 0 & 100 & 50 & 92 & 100 & 100 & 100 & 100 & 95 & 70 & 89 & 100 & 100 & 100 & 95 & 81 & 100 & 7 & 100 & 0 \\
\hline D1 & Acet & 0 & 55 & 50 & 92 & 80 & 100 & 50 & 0 & 73 & 0 & 22 & 0 & 100 & 43 & 37 & 9 & 0 & 33 & 100 & 0 \\
\hline $\mathrm{D} 2$ & cis-A & 0 & 38 & 50 & 67 & 20 & 100 & 0 & 0 & 64 & 10 & 44 & 100 & 100 & 0 & 16 & 3 & 0 & 0 & 100 & 0 \\
\hline D3 & Citric & 0 & 38 & 50 & 75 & 40 & 100 & 50 & 0 & 39 & 10 & 11 & 100 & 100 & 14 & 53 & 16 & 0 & 0 & 100 & 0 \\
\hline D4 & Form & 0 & 0 & 0 & 0 & 0 & 0 & 0 & 0 & 9 & 0 & 0 & 100 & 0 & 0 & 0 & 0 & 0 & 0 & 50 & 0 \\
\hline D5 & $\begin{array}{l}\text { D-Gala } \\
\text { lacto }\end{array}$ & 0 & 0 & 0 & 0 & 0 & 0 & 0 & 0 & 10 & 0 & 0 & 100 & 0 & 0 & 0 & 0 & 0 & 0 & 50 & 0 \\
\hline D & $\mathrm{D}-\mathrm{G}$ & 0 & 0 & 0 & 0 & 0 & 0 & 0 & 0 & & c & 0 & 10 & 0 & 1 & 0 & 0 & 0 & 0 & 50 & 0 \\
\hline D7 & D & 0 & 3 & 50 & 0 & 0 & 0 & 50 & 0 & 11 & 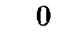 & 0 & 100 & 0 & 0 & 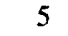 & 0 & 0 & 0 & 50 & 0 \\
\hline D8 & D & 0 & 0 & 0 & 0 & 0 & 0 & 0 & 0 & 4 & 0 & 0 & 50 & 0 & 14 & 0 & 0 & 0 & 0 & 0 & 0 \\
\hline D9 & & 0 & 0 & 0 & 0 & 0 & 0 & 100 & 0 & 1 & & 0 & 100 & 0 & & 0 & U & 0 & 0 & 50 & \\
\hline D10 & 0 & 0 & 55 & 0 & 67 & 0 & 50 & 0 & 60 & 5 & 10 & 11 & 100 & 50 & 71 & 21 & 19 & 0 & 33 & 100 & 0 \\
\hline D11 & $\beta-\mathrm{Hy}$ & 0 & 0 & 0 & 17 & 0 & 50 & 50 & 0 & 18 & 0 & 11 & 0 & 50 & 14 & 0 & 34 & 100 & 100 & 100 & 0 \\
\hline D12 & $\gamma$-Hy & 0 & 0 & 0 & 0 & 0 & 0 & 0 & 0 & ? & 0 & 0 & 0 & 50 & o & 0 & 3 & 0 & 0 & 50 & 0 \\
\hline El & $\begin{array}{l}p \text {-Hydroxyphe } \\
\text { acid }\end{array}$ & 0 & 0 & 0 & 0 & 0 & 0 & 0 & 0 & 8 & 0 & 0 & 100 & 0 & 0 & 0 & 0 & 0 & 0 & 0 & 0 \\
\hline E2 & Itaco & 0 & 0 & 0 & 0 & 0 & 0 & 0 & 0 & & 0 & 0 & 0 & 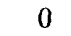 & & 0 & 0 & 0 & 0 & 0 & 0 \\
\hline E3 & & 0 & 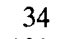 & 0 & 58 & 60 & 100 & 50 & 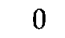 & 6 & 0 & 11 & 100 & 100 & 71 & 63 & 3 & 0 & U & 00 & \\
\hline E4 & 0 & 50 & 100 & 50 & 100 & 100 & 100 & 100 & 100 & 93 & 100 & 100 & 100 & 100 & 100 & 100 & 91 & 100 & 100 & 00 & 60 \\
\hline E5 & $\alpha$ & 0 & 3 & 0 & 0 & 20 & 0 & 0 & 0 & 5 & 0 & 0 & 0 & 50 & 0 & 0 & 6 & 0 & 100 & 100 & 0 \\
\hline E6 & & 0 & 9 & 50 & 92 & 40 & 0 & 100 & 100 & 67 & 70 & 22 & 100 & 50 & & 63 & 8. & 0 & 100 & 100 & 100 \\
\hline E7 & $\mathrm{N}$ & 0 & 5 & 50 & 4 & 0 & 100 & 0 & 0 & 5 & 0 & 22 & 100 & 100 & 29 & 89 & 3 & 0 & 0 & 0 & 0 \\
\hline E8 & Prop & 0 & 52 & 0 & 58 & 0 & 100 & 50 & 0 & 64 & 10 & 11 & 100 & 100 & 43 & 68 & 9 & 0 & 0 & 100 & 0 \\
\hline E9 & Quin & 0 & $a$ & 0 & 0 & 0 & 0 & 0 & 0 & 5 & 0 & 0 & 50 & 0 & 0 & 0 & 6 & 0 & 0 & 100 & 0 \\
\hline E10 & & 50 & 0 & 0 & 0 & 40 & 100 & 0 & 20 & 23 & & 11 & 100 & 100 & 29 & 89 & 0 & 0 & 0 & 50 & \\
\hline E11 & $S$ & 0 & 0 & 0 & 0 & 0 & 0 & 0 & 0 & 0 & 0 & 0 & 0 & 0 & 0 & 0 & 0 & 0 & 0 & 0 & 0 \\
\hline E12 & Succir & 50 & 100 & 50 & 100 & 100 & 100 & 100 & 100 & 96 & 90 & 89 & 100 & 100 & 100 & 100 & 31 & 100 & 67 & 100 & 0 \\
\hline $\mathrm{F} 1$ & & 50 & 9 & 50 & 100 & 100 & 100 & 100 & 100 & $y$ & 70 & 89 & 100 & 100 & 100 & 100 & 88 & 100 & 0 & 100 & \\
\hline F2 & & 50 & 93 & 0 & 100 & 100 & 100 & 100 & 20 & 93 & 30 & 89 & 100 & 100 & 100 & 74 & 47 & 100 & 33 & 100 & 0 \\
\hline F3 & Gluc & 0 & 0 & 0 & 0 & 0 & 0 & 50 & 0 & 8 & 0 & 0 & 100 & 0 & 0 & 0 & 0 & 0 & 0 & 0 & 0 \\
\hline F4 & Alaninamide & 0 & 93 & 100 & 83 & 100 & 100 & 100 & 20 & 89 & 60 & 89 & 100 & 100 & 100 & 84 & 94 & 0 & 100 & 100 & 60 \\
\hline
\end{tabular}


TABLE 2-Continued

\begin{tabular}{|c|c|c|c|c|c|c|c|c|c|c|c|c|c|c|c|c|c|c|c|c|c|}
\hline \multicolumn{2}{|r|}{ Carbon substrate } & \multicolumn{20}{|c|}{$\%$ of positive strains in DNA homology group: } \\
\hline $\begin{array}{l}\text { Desig- } \\
\text { nation }\end{array}$ & Name & 1 & 2 & 3 & 4 & 5 & 6 & 7 & 8 & 9 & 10 & 11 & 12 & 13 & 14 & 15 & 16 & 17 & 18 & 19 & 20 \\
\hline F5 & D-Alanine & 0 & 86 & 0 & 83 & 100 & 100 & 0 & 0 & 90 & 60 & 89 & 100 & 100 & 86 & 79 & 75 & 0 & 100 & 100 & 0 \\
\hline F6 & L-Alanine & 0 & 97 & 50 & 83 & 100 & 100 & 50 & 20 & 90 & 60 & 89 & 100 & 100 & 100 & 79 & 88 & 0 & 100 & 100 & 0 \\
\hline F7 & L-Alanylglycine & 0 & 93 & 50 & 75 & 100 & 100 & 100 & 20 & 90 & 50 & 89 & 100 & 100 & 86 & 74 & 97 & 0 & 100 & 100 & 20 \\
\hline F8 & L-Asparagine & 0 & 0 & 0 & 42 & 20 & 0 & 0 & 0 & 15 & 0 & 0 & 100 & 0 & 14 & 0 & 16 & 0 & 0 & 100 & 0 \\
\hline F9 & L-Aspartic acid & 0 & 48 & 0 & 58 & 60 & 50 & 100 & 20 & 60 & 0 & 33 & 100 & 50 & 43 & 16 & 56 & 80 & 67 & 100 & 0 \\
\hline F10 & L-Glutamic acid & 100 & 100 & 0 & 100 & 100 & 100 & 100 & 100 & 97 & 80 & 100 & 100 & 100 & 100 & 100 & 97 & 100 & 67 & 100 & 40 \\
\hline F11 & Glycyl-L-aspartic acid & 0 & 0 & 0 & 58 & 20 & 100 & 0 & 0 & 37 & 10 & 11 & 100 & 50 & 0 & 0 & 25 & 80 & 0 & 50 & 0 \\
\hline F12 & Glycyl-L-glutamic acid & 0 & 83 & 50 & 92 & 100 & 100 & 100 & 80 & 90 & 80 & 67 & 100 & 100 & 86 & 63 & 72 & 100 & 67 & 100 & 0 \\
\hline $\mathrm{G} 1$ & L-Histidine & 0 & 3 & 0 & 17 & 0 & 0 & 0 & 0 & 15 & 0 & 0 & 100 & 0 & 14 & 0 & 0 & 0 & 0 & 0 & 0 \\
\hline G2 & Hydroxy-L-proline & 0 & 24 & 0 & 58 & 80 & 100 & 0 & 0 & 63 & 0 & 89 & 50 & 100 & 29 & 42 & 50 & 20 & 100 & 100 & 0 \\
\hline G3 & L-Leucine & 0 & 0 & 0 & 33 & 0 & 50 & 0 & 0 & 12 & 0 & 11 & 50 & 100 & 29 & 5 & 3 & 0 & 0 & 100 & 0 \\
\hline G4 & L-Ornithine & 0 & 3 & 0 & 8 & 0 & 50 & 0 & 0 & 11 & 0 & 0 & 50 & 0 & 0 & 0 & 0 & 0 & 0 & 0 & 0 \\
\hline G5 & L-Phenylalanine & 0 & 0 & 0 & 0 & 0 & 50 & 0 & 0 & 5 & 0 & 0 & 100 & 0 & 14 & 0 & 0 & 0 & 0 & 100 & 0 \\
\hline G6 & L-Proline & 0 & 28 & 50 & 67 & 60 & 100 & 50 & 20 & 66 & 0 & 22 & 100 & 100 & 43 & 47 & 3 & 0 & 33 & 50 & 20 \\
\hline G7 & L-Pyroglutamic acid & 0 & 3 & 0 & 0 & 0 & 0 & 0 & 0 & 5 & 0 & 0 & 0 & 0 & 0 & 0 & 3 & 0 & 0 & 0 & 0 \\
\hline G8 & D-Serine & 0 & 0 & 0 & 8 & 0 & 0 & 0 & 0 & 3 & 0 & 0 & 0 & 0 & 14 & 0 & 0 & 0 & 0 & 0 & 0 \\
\hline G9 & L-Serine & 0 & 93 & 50 & 83 & 100 & 100 & 100 & 100 & 84 & 0 & 44 & 100 & 100 & 100 & 84 & 59 & 80 & 67 & 100 & 0 \\
\hline G10 & L-Threonine & 0 & 21 & 50 & 50 & 40 & 50 & 0 & 0 & 53 & 0 & 11 & 100 & 100 & 29 & 21 & 6 & 60 & 67 & 100 & 0 \\
\hline G11 & DL-Carnitine & 0 & 0 & 0 & 0 & 20 & 0 & 0 & 0 & 3 & 0 & 0 & 0 & 0 & 0 & 0 & 3 & 0 & 0 & 0 & 0 \\
\hline G12 & $\gamma$-Aminobutyric acid & 0 & 0 & 0 & 0 & 0 & 0 & 50 & 0 & 3 & 0 & 0 & 0 & 0 & 0 & 0 & 3 & 0 & 0 & 0 & 0 \\
\hline $\mathrm{H} 1$ & Urocanic acid & 0 & 3 & 0 & 17 & 0 & 0 & 0 & 0 & 19 & 10 & 0 & 100 & 0 & 14 & 0 & 0 & 20 & 0 & 0 & 0 \\
\hline H2 & Inosine & 0 & 7 & 0 & 42 & 60 & 0 & 50 & 0 & 52 & 0 & 0 & 100 & 0 & 14 & 21 & 0 & 20 & 33 & 50 & 0 \\
\hline $\mathrm{H} 3$ & Uridine & 0 & 7 & 0 & 42 & 80 & 0 & 0 & 0 & 49 & 0 & 0 & 100 & 50 & 14 & 5 & 12 & 40 & 67 & 50 & 0 \\
\hline $\mathrm{H} 4$ & Thymidine & 0 & 0 & 50 & 0 & 0 & 0 & 50 & 0 & 9 & 0 & 0 & 100 & 0 & 0 & 0 & 0 & 0 & 0 & 0 & 0 \\
\hline H5 & Phenyl ethylamine & 0 & 3 & 0 & 0 & 0 & 0 & 0 & 0 & 3 & 0 & 0 & 0 & 0 & 0 & 0 & 0 & 0 & 0 & 0 & 0 \\
\hline H6 & Putrescine & 0 & 0 & 0 & 0 & 0 & 0 & 0 & 0 & 2 & 0 & 0 & 0 & 0 & 0 & 0 & 0 & 0 & 0 & 0 & 0 \\
\hline $\mathrm{H} 7$ & 2-Aminoethanol & 0 & 0 & 0 & 0 & 20 & 0 & 0 & 0 & 1 & 0 & 0 & 0 & 0 & 0 & 0 & 0 & 0 & 0 & 0 & 0 \\
\hline $\mathrm{H} 8$ & 2,3-Butanediol & 0 & 0 & 0 & 0 & 0 & 0 & 0 & 0 & 4 & 0 & 0 & 0 & 50 & 14 & 0 & 3 & 0 & 33 & 50 & 0 \\
\hline H9 & Glycerol & 0 & 48 & 50 & 92 & 20 & 100 & 50 & 80 & 66 & 0 & 22 & 100 & 50 & 71 & 37 & 50 & 100 & 67 & 100 & 0 \\
\hline H10 & DL- $\alpha$-Glycerolphosphat & 0 & 45 & 0 & 33 & 20 & 0 & 50 & 0 & 53 & 0 & 0 & 100 & 0 & 57 & 5 & 9 & 20 & 67 & 50 & 0 \\
\hline H11 & Glucose 1-phosphate & 0 & 34 & 0 & 17 & 20 & 0 & 50 & 0 & 51 & 0 & 0 & 100 & 0 & 14 & 26 & 25 & 100 & 67 & 0 & 0 \\
\hline $\mathrm{H} 12$ & Glucose 6-phosphate & 0 & 24 & 0 & 0 & 0 & 0 & 50 & 0 & 40 & 0 & 0 & 100 & 0 & 0 & 26 & 19 & 100 & 67 & 0 & 0 \\
\hline
\end{tabular}

Group 12 (X. campestris pv. pisi) and group 20 (X. albilineans) were responsible for most of the atypical reactions within the genus.

Proposal for a new classification. By synthesizing data derived from comparative protein electrophoresis and FAME analyses in previous studies $(48,51,52,60)$ and the DNA hybridization data reported in this study, we obtained a new picture of the internal relationships of the genus Xanthomonas. On the basis of the DNA homology matrix data, the $X$. campestris pathovars do not belong to a single species, but belong to 15 genotypic groups. Since DNA hybridization experiments measure levels of total genomic homology, this technique is the most reliable substitute for DNA sequence comparison and has been recommended as the standard criterion for designating species $(29,38,56)$; levels of DNA homology of 60 to $70 \%$ are considered the minimum levels for strains belonging to the same species. Sufficient evidence is now available to classify each of the DNA homology groups as a separate species of the genus Xanthomonas.

The revised classification described below is based on genomic relatedness data rather than phenotypic and phytopathogenic specialization data. Such a classification should allow avirulent xanthomonads, which are regarded increasingly as important from an ecological point of view, to be identified on the basis of genotypic relatedness data. In addition, previously undetected relationships should become evident. Obvious examples are found in group 15, which harbors the pathovars isolated from crucifers, and group 16 , which contains most
TABLE 3. Phenotypic significance of the Xanthomonas DNA homology groups based on Biolog GN microplate assay data

\begin{tabular}{cccc}
\hline $\begin{array}{c}\text { DNA } \\
\text { homology } \\
\text { group }\end{array}$ & $\begin{array}{c}\text { No. of } \\
\text { strains } \\
\text { tested }\end{array}$ & $\begin{array}{c}\text { Relative } \\
\text { homogeneity } \\
\text { value }^{a}\end{array}$ & $\begin{array}{c}\text { No. of } \\
\text { groups } \\
\text { differentiated }\end{array}$ \\
\hline 1 & 2 & 0.89 & 18 \\
2 & 29 & 0.79 & 15 \\
3 & 2 & 0.73 & 19 \\
4 & 12 & 0.77 & 15 \\
5 & 5 & 0.81 & 15 \\
6 & 2 & 0.89 & 19 \\
7 & 2 & 0.68 & 19 \\
8 & 5 & 0.92 & 17 \\
9 & 99 & 0.67 & 10 \\
10 & 10 & 0.84 & 16 \\
11 & 9 & 0.83 & 12 \\
12 & 2 & 0.95 & 19 \\
13 & 2 & 0.85 & 18 \\
14 & 7 & 0.79 & 14 \\
15 & 19 & 0.81 & 18 \\
16 & 32 & 0.77 & 14 \\
17 & 5 & 0.92 & 19 \\
18 & 13 & 0.82 & 19 \\
19 & 2 & 0.84 & 19 \\
20 & 5 & 0.95 & 19 \\
\hline
\end{tabular}

${ }^{a}$ See text. 


\begin{tabular}{|c|c|c|c|c|c|c|c|c|c|c|c|c|}
\hline & 1 & 2 & 3 & 4 & 5 & 6 & 7 & 8 & 9 & 10 & 11 & 12 \\
\hline A & & 5 & 91 & 76 & 56 & 68 & 7 & 72 & 3 & 17 & 4 & 90 \\
\hline B & 0 & 99 & 73 & 73 & 85 & 99 & 2 & 11 & 53 & 95 & 8 & 96 \\
\hline C & 60 & 8 & 93 & 24 & 5 & 17 & 69 & 96 & 43 & 1 & 99 & 90 \\
\hline D & 50 & 40 & 35 & 5 & 5 & 5 & 7 & 2 & 6 & 42 & 18 & 2 \\
\hline$E$ & 4 & 1 & 44 & 94 & 6 & 71 & 41 & 45 & 4 & 21 & 0 & 92 \\
\hline $\mathbf{F}$ & 91 & 79 & 4 & 85 & 78 & 83 & 83 & 12 & 49 & 95 & 26 & 81 \\
\hline G & 8 & 49 & 11 & 6 & 4 & 44 & 3 & 2 & 76 & 35 & 2 & 2 \\
\hline H & 11 & 28 & 29 & 5 & 2 & 1 & 1 & 4 & 56 & 33 & 34 & 27 \\
\hline
\end{tabular}

Negative for more than $90 \%$ of the strains and not positive for any of the DNA homology groups.
Negative for more than $90 \%$ of the strains.
Variable reaction.
Positive for more than $90 \%$ of the strains.
Positive for more than $90 \%$ of the strains and not negative for any of the DNA homology groups.

FIG. 3. Average reactions of members of the genus Xanthomonas with 95 carbon compounds in the GN microplate assay, with the characteristic compounds indicated. The names of the carbon compounds used, as defined by letters (rows) and numbers (columns), are given in Table 2.

of the pathovars isolated from members of the Poaceae. Knowledge concerning the relationships among these pathogens can help us understand their mechanism of infection.

In the revised classification described below, the previously described species $X$. albilineans, $X$. fragariae, $X$. oryzae, and $X$. populi are not affected. The type species, $X$. campestris (Pammel 1895) Dowson 1939, is emended to include only DNA homology group 15 (i.e., the pathovars obtained from crucifers). $X$. axonopodis Starr and Garces 1950 is emended to include all of the former $X$. campestris group 9 pathovars. We propose the following species names for the other Xanthomonas DNA homology groups (Table 1): Xanthomonas hortorum for group 2; Xanthomonas arboricola for group 4; Xanthomonas cassavae for group 5; Xanthomonas codiaei for group 6; Xanthomonas bromi for group 7; Xanthomonas cucurbitae for group 8; Xanthomonas vasicola for group 11; Xanthomonas pisi for group 12; Xanthomonas melonis for group 13; Xanthomonas vesicatoria for group 14; Xanthomonas translucens for group 16; Xanthomonas hyacinthi for group 17; Xanthomonas theicola for group 18; and Xanthomonas sacchari for group 19.

The elevation of pathovars to species rank falls outside the nomenclatural statements concerning the international standards for naming pathovars of phytopathogenic bacteria (18), but is subject to the rules of the International Code of Nomenclature of Bacteria (31a). For all nomenclatural changes we have taken a rather conservative viewpoint, respecting as much as possible phytopathological relevance. We have applied the rules of the International Code of Nomenclature of Bacteria in assigning the species name $X$. campestris to group 15 , which contains type strain LMG 568 (= NCPPB 528), and the name $X$. axonopodis to group 9 . Rather than adopting the name of the oldest described pathovar as the species epithet, we preferred to use a more general name in those cases where pathovars from diverse host plants constitute a new species (e.g., $X$. arboricola for pathogens of trees). New names were also proposed when the new species does not include the pathovar reference strain of the former $X$. campestris pathovar $(X$. codiaei for former $X$. campestris pv. poinsettiicola type B strains; $X$. bromi for strains obtained from bromegrass; $X$. sacchar for strains obtained from Guadeloupe and received as $X$. albilineans).

Since the relevance of the host specificity of most of the pathovars has not been determined and for phytopathological reasons we retained the pathovar designations as infrasubspecific epithets within the new species.

Description of the genus Xanthomonas Dowson 1939. The description below is based on the phenotypic description of Bradbury (7), as revised by Van den Mooter and Swings (46) and Palleroni and Bradbury (36), as well as the results of Yang et al. $(58,60)$, Auling et al. (2), and this study. G+C content data were obtained from the studies of De Vos and De Ley (14), Vera Cruz et al. (53), Van den Mooter et al. $(44,45)$, and Vauterin et al. (50; this study).

Xanthomonads are plant pathogens or are associated with plants. Most xanthomonad strains form yellow mucoid smooth colonies. The yellow pigments are mono- or dibromo arylpolyenes called xanthomonadins (1), which are characteristic of the genus. The exopolysaccharide xanthan, which is responsible for the mucoid or viscous cultures, is typical of the genus.

The cells are gram-negative rods which are 0.4 to 0.6 by 1.0 to $2.9 \mu \mathrm{m}$. They occur mostly alone or in pairs, but chains occur as well. Filamentous cells are occasionally seen. Cells are usually motile by means of one polar flagellum.

Catalase is present, but urease and indole are not produced. Nitrate is not reduced to nitrite. Oxidase is absent or only weakly reactive. Acetoin is not formed. Litmus milk is not acidified. There is no growth at pH 4.5 or at 4 or $37^{\circ} \mathrm{C}$. Growth is inhibited by $6 \% \mathrm{NaCl}, 30 \%$ glucose, $0.01 \%$ methyl green, 
$0.01 \%$ thionin, $0.01 \%$ lead acetate, or $0.1 \%$ triphenyl tetrazoliumchloride. Strains are usually susceptible to erythromycin and tetracycline. Small amounts of acid are produced from many carbohydrates but not from L-rhamnose, adonitol, sorbose, D-sorbitol, meso-erythritol, or meso-inositol. Glycine, Lglutamine, and L-asparagine are not utilized as sole carbon and nitrogen sources. Xanthomonas strains are chemoorganotrophic. One or more growth factors may be required.

Xanthomonas strains contain the following nine fatty acids: 11:0 iso, 11:0 iso $3 \mathrm{OH}, 12: 03 \mathrm{OH}, 13: 0$ iso $3 \mathrm{OH}, 15: 0$ iso, $16: 1$ cis-9, 16:0, 17:1 iso F, and 17:0 iso. Among these fatty acids, 11:0 iso, $11: 0$ iso $3 \mathrm{OH}$, and 13:0 iso $3 \mathrm{OH}$ are characteristic of the genus and are useful criteria for differentiating Xanthomonas strains from other bacteria.

Xanthomonas strains contain spermidine as the major polyamine. Spermine is usually present in detectable amounts, whereas 2-hydroxyputrescine, 1,3-diaminopropane, and putrescine are never present. Some strains contain cadaverine.

As determined by the Biolog GN microplate test, the following carbon compounds are oxidized by at least $94 \%$ of the strains (and thus these reactions are characteristic of the genus): D-fructose, $\alpha$-D-glucose, D-mannose, methylpyruvate, and $\alpha$-ketoglutaric acid. The following carbon compounds are not oxidized by more than $94 \%$ of the strains: $\alpha$-cyclodextrin, adonitol, D-arabitol, meso-erythritol, meso-inositol, xylitol, Dglucosaminic acid, $\gamma$-hydroxybutyric acid, itaconic acid, sebacic acid, L-ornithine, L-pyroglutamic acid, D-serine, DL-carnitine, $\gamma$-aminobutyric acid, phenyl ethylamine, putrescine, 2-aminoethanol, and 2,3 butanediol.

The $\mathrm{G}+\mathrm{C}$ contents of members of the genus range from 63.3 to $69.7 \mathrm{~mol} \%$. The type species is Xanthomonas campestris.

Description of Xanthomonas campestris (Pammel 1895) Dowson 1939 emend. The description of $X$. campestris is the same as that of the genus. Strains of this species cause disease in various crucifers (members of the Brassicaceae). This species can be subdivided into the following pathovars on the basis of isolation from certain hosts: $X$. campestris pv. aberrans, $X$. campestris pv. armoraciae, $X$. campestris pv. barbareae, $X$. campestris pv. campestris, $X$. campestris pv. incanae, $X$. campestris pv. raphani and (based on work by Palleroni et al. [37]) $X$. campestris pv. plantaginis. Strains of $X$. campestris pv. aberrans and $X$. campestris pv. raphani have been found to induce disease symptoms in cabbage and radish similar to the disease symptoms induced by $X$. campestris pv. campestris (50a), and hence the relevance of these two pathovars can be questioned.

$X$. campestris can be distinguished from other Xanthomonas species by the presence of metabolic activity on the carbon substrates dextrin, glycogen, $N$-acetyl-D-glucosamine, cellobiose, L-fucose, D-galactose, gentiobiose, lactulose, maltose, Dmelibiose, D-psicose, D-trehalose, monomethylsuccinate, malonic acid, D-saccharic acid, succinic acid, bromosuccinic acid, and L-glutamic acid and by a lack of metabolic activity on the carbon substrates $N$-acetyl-D-galactosamine, L-arabinose, $\alpha$-Dlactose, D-mannitol, $\beta$-methyl-D-glucoside, L-rhamnose, D-sorbitol, formic acid, D-galactonic acid lactone, D-galacturonic acid, D-gluconic acid, D-glucuronic acid, $\beta$-hydroxybutyric acid, $p$-hydroxyphenylacetic acid, $\alpha$-ketovaleric acid, quinic acid, glucuronamide, L-asparagine, glycyl-L-aspartic acid, L-histidine, L-leucine, L-phenylalanine, urocanic acid, uridine, thymidine, and DL- $\alpha$-glycerolphosphate.

$X$. campestris is the type species of the genus, and its $\mathrm{G}+\mathrm{C}$ content is 65.8 to $66.6 \mathrm{~mol} \%$ (68.0 to $68.3 \mathrm{~mol} \%$ for $X$. campestris pv. incanae). The type strain is LMG $568(=$ NCPPB $528=$ ICMP $13=$ ATCC $33913=$ DSM 3586).

Description of Xanthomonas arboricola sp. nov. Xanthomonas arboricola (ar.bo.ri'co.la L. fem. n. arbor, tree; L. v. colere, to inhabit; L. adj. arboricola, living in trees). The description of $X$. arboricola is the same as that of the genus. The following pathovars are distinguished on the basis of phytopathogenic specialization: $X$. arboricola pv. corylina, $X$. arboricola pv. juglandis, $X$. arboricola pv. poinsettiicola, $X$. arboricola pv. populi, $X$. arboricola pv. pruni, and (based on work by Palleroni et al. [37]) $X$. arboricola pv. celebensis. $X$. arboricola pv. poinsettiicola includes the type $C$ strains of the former taxon $X$. campestris pv. poinsettiicola.

$X$. arboricola can be distinguished from other Xanthomonas species by the presence of metabolic activity on the carbon substrates dextrin, glycogen, Tween $80, N$-acetyl-D-glucosamine, cellobiose, L-fucose, D-galactose, gentiobiose, maltose, D-psicose, D-trehalose, monomethylsuccinate, acetic acid, DLlactic acid, succinic acid, bromosuccinic acid, succinamic acid, L-glutamic acid, glycyl-L-glutamic acid, and glycerol and by a lack of metabolic activity on the carbon substrates $N$-acetyl-Dgalactosamine, L-arabinose, D-mannitol, $\beta$-methyl-D-glucoside, $D$-raffinose, L-rhamnose, formic acid, D-galactonic acid lactone, D-galacturonic acid, D-gluconic acid, D-glucuronic acid, $p$-hydroxyphenylacetic acid, $\alpha$-ketovaleric acid, quinic acid, D-saccharic acid, glucuronamide, L-phenylalanine, thymidine, and glucose 6-phosphate.

The $\mathrm{G}+\mathrm{C}$ content is 66.0 to $67.0 \mathrm{~mol} \%$. The type strain is $X$. arboricola pv. juglandis LMG 747 (= NCPPB $411=$ ICMP 35).

Description of Xanthomonas axonopodis Starr and Garces 1950 emend. The description of $X$. axonopodis is the same as that of the genus. The following pathovars are distinguished on the basis of phytopathogenic specialization on a wide variety of host plants: $X$. axonopodis pv. axonopodis, $X$. axonopodis pv. alfalfae, $X$. axonopodis pv. bauhiniae, $X$. axonopodis pv. begoniae, $X$. axonopodis pv. cajani, $X$. axonopodis pv. cassavae, $X$. axonopodis pv. cassiae, $X$. axonopodis pv. citri (formerly $X$. campestris pv. citri group A strains [24]), $X$. axonopodis pv. aurantifolii (formerly $X$. campestris pv. citri group B, C, and D strains; reclassified as $X$. campestris pv. aurantifolii by Gabriel et al. [22]), $X$. axonopodis pv. citrumelo (formerly $X$. campestris pv. citri group E strains; reclassified as $X$. campestris pv. citrumelo by Gabriel et al. [22]), $X$. axonopodis pv. clitoriae, $X$. axonopodis pv. coracanae, $X$. axonopodis pv. cyamopsidis, $X$. axonopodis pv. desmodii, $X$. axonopodis pv. desmodiigangetici, $X$. axonopodis pv. desmodiilaxiflori, $X$. axonopodis pv. desmodiirotundifolii, $X$. axonopodis pv. dieffenbachiae, $X$. axonopodis pv. erythrinae, $X$. axonopodis pv. glycines, $X$. axonopodis pv. lespedezae, $X$. axonopodis pv. malvacearum, $X$. axonopodis pv. manihotis, $X$. axonopodis pv. patelii, $X$. axonopodis pv. phaseoli, $X$. axonopodis pv. phaseoli-fuscans, $X$. axonopodis pv. phyllanthi, $X$. axonopodis pv. poinsettiicola, $X$. axonopodis pv. rhynchosiae, $X$. axonopodis pv. ricini, $X$. axonopodis pv. sesbaniae, $X$. axonopodis pv. tamarindi, $X$. axonopodis pv. vasculorum, $X$. axonopodis pv. vesicatoria, $X$. axonopodis pv. vignaeradiatae, $X$. axonopodis pv. vignicola, and $X$. axonopodis pv. vitians, as well as (based on work by Palleroni et al. [37]) $X$. axonopodis pv. betlicola, $X$. axonopodis pv. biophyti, $X$. axonopodis pv. fascicularis, $X$. axonopodis pv. khayae, $X$. axonopodis pv. maculifoliigardeniae, $X$. axonopodis pv. martyniicola, $X$. axonopodis pv. melhusii, $X$. axonopodis pv. nakataecorchori, $X$. axonopodis pv. pedalii, $X$. axonopodis pv. physalidicola, and $X$. axonopodis pv. punicae. The following pathovars include the type A strains of the corresponding former $X$. campestris pathovars: $X$. axonopodis pv. poinsettiicola, $X$. axonopodis pv. vasculorum, $X$. axonopodis pv. vesicatoria, and $X$. axonopodis pv. vitians. $X$. axonopodis pv. cassavae includes the type B strains of the former taxon $X$. campestris pv. cassavae.

$X$. axonopodis can be distinguished from other Xanthomonas species by the presence of metabolic activity on the carbon 
substrates dextrin, cellobiose, gentiobiose, maltose, D-psicose, D-trehalose, monomethylsuccinate, succinic acid, bromosuccinic acid, succinamic acid, D-alanine, L-alanine, L-alanylglycine, L-glutamic acid, and glycyl-L-glutamic acid and by a lack of metabolic activity on the carbon substrates $\beta$-methyl-D-glucoside, L-rhamnose, formic acid, D-galactonic acid lactone, Dgalacturonic acid, D-glucuronic acid, $p$-hydroxyphenylacetic acid, $\alpha$-ketovaleric acid, quinic acid, glucuronamide, L-phenylalanine, and thymidine.

The $\mathrm{G}+\mathrm{C}$ content is 65.0 to $67.6 \mathrm{~mol} \%$. The type strain is LMG 538 ( = NCPPB $457=$ ATCC $19312=$ ICMP $50=$ DSM 3585).

Description of Xanthomonas bromi sp. nov. Xanthomonas bromi (bro'mi. L. masc. gen. n. bromi, from bromegrass). The description of $X$. bromi is the same as that of the genus. Strains of this species cause wilting disease on bromegrass (Bromus spp.).

$X$. bromi can be distinguished from other xanthomonads by its SDS-PAGE protein patterns and FAME profiles (51), by the presence of metabolic activity on the carbon substrates dextrin, $N$-acetyl-D-glucosamine, cellobiose, D-galactose, gentiobiose, maltose, D-psicose, sucrose, D-trehalose, turanose, monomethylsuccinate, D-glucuronic acid, DL-lactic acid, succinic acid, bromosuccinic acid, succinamic acid, alaninamide, L-alanylglycine, L-aspartic acid, L-glutamic acid, glycyl-L-glutamic acid, and L-serine, and by a lack of metabolic activity on the carbon substrates $N$-acetyl-D-galactosamine, D-raffinose, cis-aconitic acid, formic acid, D-galactonic acid lactone, D-galacturonic acid, $\alpha$-hydroxybutyric acid, $p$-hydroxyphenylacetic acid, $\alpha$-ketovaleric acid, malonic acid, quinic acid, D-saccharic acid, D-alanine, L-asparagine, glycyl-L-aspartic acid, L-histidine, hydroxy-L-proline, L-leucine, L-phenylalanine, L-threonine, urocanic acid, and uridine.

The $\mathrm{G}+\mathrm{C}$ content is $65.6 \mathrm{~mol} \%$. The type strain is LMG 947 (= CFBP 1976).

Description of Xanthomonas cassavae (ex Wiehe and Dowson 1953) sp. nov., nom. rev. Strains of this species are pathogenic for Manihot spp. (Euphorbiaceae). The description of $X$. cassavae is the same as that of the genus. $X$. cassavae includes the type A strains of the former $\operatorname{tax} X$. campestris pv. cassavae.

$X$. cassavae can be distinguished from the other Xanthomonas species on the basis of SDS-PAGE protein patterns and FAME profiles $(48,60)$. $X$. cassavae can also be distinguished from other Xanthomonas species by the presence of metabolic activity on the carbon substrates L-fucose, gentiobiose, maltose, D-melibiose, D-trehalose, monomethylsuccinate, succinic acid, bromosuccinic acid, succinamic acid, alaninamide, D-alanine, L-alanine, L-alanylglycine, L-glutamic acid, glycyl-L-glutamic acid, and L-serine and by a lack of metabolic activity on the carbon substrates $\alpha$-D-lactose, D-mannitol, $\beta$-methyl-D-glucoside, D-raffinose, L-rhamnose, D-sorbitol, formic acid, D-galactonic acid lactone, D-galacturonic acid, D-gluconic acid, Dglucuronic acid, $\alpha$-hydroxybutyric acid, $\beta$-hydroxybutyric acid, $p$-hydroxyphenylacetic acid, malonic acid, propionic acid, quinic acid, glucuronamide, L-histidine, L-leucine, L-phenylalanine, urocanic acid, thymidine, and glucose 6-phosphate.

The $\mathrm{G}+\mathrm{C}$ content is 64.2 to $66.1 \mathrm{~mol} \%$. The type strain is LMG 673 (= NCPPB 101 = ICMP 204).

Description of Xanthomonas codiaei sp. nov. Xanthomonas codiaei (co.di.ae'i. L. neut. gen. n. codiaei, from croton). The description of $X$. codiaei is the same as that of the genus. Strains of this species cause wilting disease on Codiaeum variegatum. $X$. codiaei includes the type B strains of the former taxon $X$. campestris pv. poinsettiicola.

$X$. codiaei can be distinguished from other Xanthomonas species by its SDS-PAGE protein patterns (48), by the pres- ence of metabolic activity on the carbon substrates dextrin, glycogen, Tween 40 , Tween $80, N$-acetyl-D-glucosamine, cellobiose, $D$-galactose, gentiobiose, $\alpha$-D-lactose, lactulose, maltose, D-melibiose, $\beta$-methyl-D-glucoside, D-psicose, sucrose, D-trehalose, turanose, monomethylsuccinate, acetic acid, cis-aconitic acid, citric acid, $\alpha$-ketobutyric acid, malonic acid, propionic acid, D-saccharic acid, succinic acid, bromosuccinic acid, succinamic acid, alaninamide, D-alanine, L-alanine, L-alanylglycine, L-glutamic acid, glycyl-L-aspartic acid, glycyl-L-glutamic acid, hydroxy-L-proline, L-proline, L-serine, and glycerol, and by a lack of metabolic activity on the carbon substrates $N$ acetyl-D-galactosamine, L-arabinose, L-fucose, L-rhamnose, formic acid, D-galactonic acid lactone, D-galacturonic acid, Dgluconic acid, D-glucuronic acid, $p$-hydroxyphenylacetic acid, $\alpha$-ketovaleric acid, DL-lactic acid, quinic acid, glucuronamide, L-asparagine, L-histidine, urocanic acid, inosine, uridine, thymidine, DL- $\alpha$-glycerolphosphate, glucose 1-phosphate, and glucose 6-phosphate.

The $\mathrm{G}+\mathrm{C}$ content is $66.3 \mathrm{~mol} \%$. The type strain is LMG 8678 (= ICMP 9513).

Description of Xanthomonas cucurbitae (ex Bryan 1926) sp. nov., nom. rev. The description of $X$. cucurbitae is the same as that of the genus. Strains of this species are isolated from diseased Citrullus vulgaris, Cucumis sativus, and Cucurbita spp. (Cucurbitaceae).

$X$. cucurbitae can be distinguished from other Xanthomonas species on the basis of its SDS-PAGE protein patterns (48), by the presence of metabolic activity on the carbon substrates dextrin, glycogen, cellobiose, maltose, D-psicose, D-trehalose, monomethylsuccinate, DL-lactic acid, succinic acid, bromosuccinic acid, L-glutamic acid, and L-serine, and by a lack of metabolic activity on the carbon substrates $N$-acetyl-D-galactosamine, L-arabinose, gentiobiose, $\alpha$-D-lactose, lactulose, D-mannitol, $\beta$-methyl-D-glucoside, D-raffinose, L-rhamnose, D-sorbitol, sucrose, turanose, acetic acid, cis-aconitic acid, citric acid, formic acid, D-galactonic acid lactone, D-galacturonic acid, D-gluconic acid, D-glucuronic acid, $\beta$-hydroxybutyric acid, $p$-hydroxyphenylacetic acid, $\alpha$-ketobutyric acid, $\alpha$-ketovaleric acid, malonic acid, propionic acid, quinic acid, glucuronamide, D-alanine, Lasparagine, glycyl-L-aspartic acid, L-histidine, hydroxy-L-proline, L-leucine, L-phenylalanine, L-threonine, urocanic acid, inosine, uridine, thymidine, DL- $\alpha$-glycerolphosphate, glucose 1-phosphate, and glucose 6-phosphate.

The $\mathrm{G}+\mathrm{C}$ content is 66.1 to $66.8 \mathrm{~mol} \%$. The type strain is LMG 690 (= NCPPB 2597 = ICMP 2299).

Description of Xanthomonas hortorum sp. nov. Xanthomonas hortorum (hor.to'rum. L. masc. gen. n. hortorum, from gardens). The description of $X$. hortorum is the same as that of the genus. The following pathovars are distinguished on the basis of phytopathogenic specialization: $X$. hortorum pv. hederae, $X$. hortorum pv. pelargonii, and $X$. hortorum pv, vitians. $X$. hortorum pv. carotae and $X$. hortorum pv. taraxaci have been distinguished on the basis of hybridization data by Palleroni et al. (37).

$X$. hortorum pv. hederae and $X$. hortorum pv. vitians together can be distinguished as a separate group from other xanthomonads on the basis of the results of SDS-PAGE of proteins, whereas $X$. hortorum pv. pelargonii constitutes a separate group (48). On the basis of FAME analysis data, $X$. hortorum pv. pelargonii and $X$. hortorum pv. hederae together form a distinct group (60). $X$. hortorum can be distinguished from other Xanthomonas species by the presence of metabolic activity on the carbon substrates cellobiose, gentiobiose, maltose, D-melibiose, D-psicose, D-trehalose, monomethylsuccinate, DLlactic acid, succinic acid, bromosuccinic acid, succinamic acid, alaninamide, L-alanine, L-alanylglycine, L-glutamic acid, and 
L-serine and by a lack of metabolic activity on the carbon substrates $N$-acetyl-D-galactosamine, L-arabinose, $\alpha$-D-lactose, D-mannitol, $\beta$-methyl-D-glucoside, L-rhamnose, D-sorbitol, formic acid, D-galactonic acid lactone, D-galacturonic acid, Dgluconic acid, D-glucuronic acid, $\beta$-hydroxybutyric acid, $p$-hydroxyphenylacetic acid, $\alpha$-ketovaleric acid, quinic acid, D-saccharic acid, glucuronamide, L-asparagine, glycyl-L-aspartic acid, L-histidine, L-leucine, L-phenylalanine, urocanic acid, inosine, uridine, and thymidine.

The $\mathrm{G}+\mathrm{C}$ content is 63.6 to $65.1 \mathrm{~mol} \%$. The type strain is $X$. hortorum pv. hederae LMG 733 (= NCPPB 939 = ICMP 453).

Description of Xanthomonas hyacinthi (ex Wakker 1883) sp. nov., nom. rev. The description of $X$. hyacinthi is the same as that of the genus. Strains of this species cause wilting disease in Hyacinthus orientalis.

$X$. hyacinthi strains have very distinct SDS-PAGE protein and FAME profiles $(48,60)$. This species can be distinguished from other Xanthomonas species by the presence of metabolic activity on the carbon substrates dextrin, glycogen, cellobiose, D-galactose, gentiobiose, maltose, D-psicose, sucrose, D-trehalose, monomethylsuccinate, $\beta$-hydroxybutyric acid, succinic acid, bromosuccinic acid, succinamic acid, L-glutamic acid, glycyl-L-glutamic acid, glycerol, glucose 1-phosphate, and glucose 6-phosphate and by a lack of metabolic activity on the carbon substrates $N$-acetyl-D-galactosamine, L-fucose, $\alpha$-D-lactose, lactulose, D-mannitol, D-melibiose, D-raffinose, L-rhamnose, Dsorbitol, acetic acid, cis-aconitic acid, citric acid, formic acid, D-galactonic acid lactone, D-galacturonic acid, D-gluconic acid, D-glucuronic acid, $\alpha$-hydroxybutyric acid, $p$-hydroxyphenylacetic acid, $\alpha$-ketobutyric acid, $\alpha$-ketovaleric acid, DL-lactic acid, malonic acid, propionic acid, quinic acid, D-saccharic acid, glucuronamide, alaninamide, D-alanine, L-alanine, L-alanylglycine, L-asparagine, L-histidine, L-leucine, L-phenylalanine, Lproline, and thymidine.

The $\mathrm{G}+\mathrm{C}$ content is 69.2 to $69.3 \mathrm{~mol} \%$. The type strain is LMG 739 (= NCPPB 599 = ICMP 189 = ATCC $19314=$ CFBP 1156).

Description of Xanthomonas melonis sp. nov. Xanthomonas melonis (me.lo'nis. L. fem. gen. n. melonis, from melon). The description of $X$. melonis is the same as that of the genus. The strains of this species are isolated from diseased melons $(\mathrm{Cu}$ cumis melo).

$X$. melonis can be distinguished from other Xanthomonas species by the presence of metabolic activity on the carbon substrates dextrin, glycogen, Tween 40 , Tween $80, N$-acetyl-Dglucosamine, cellobiose, L-fucose, D-galactose, gentiobiose, lactulose, maltose, D-melibiose, D-psicose, sucrose, D-trehalose, monomethylsuccinate, acetic acid, cis-aconitic acid, citric acid, $\alpha$-ketobutyric acid, malonic acid, propionic acid, D-saccharic acid, succinic acid, bromosuccinic acid, succinamic acid, alaninamide, D-alanine, L-alanine, L-alanylglycine, L-glutamic acid, glycyl-L-glutamic acid, hydroxy-L-proline, L-leucine, L-proline, L-serine, and L-threonine and by a lack of metabolic activity on the carbon substrates $N$-acetyl-D-galactosamine, L-arabinose, D-mannitol, L-rhamnose, D-sorbitol, formic acid, D-galactonic acid lactone, D-galacturonic acid, D-gluconic acid, D-glucuronic acid, p-hydroxyphenylacetic acid, quinic acid, glucuronamide, L-asparagine, L-histidine, L-phenylalanine, urocanic acid, inosine, thymidine, DL- $\alpha$-glycerolphosphate, glucose 1-phosphate, and glucose 6-phosphate.

The $\mathrm{G}+\mathrm{C}$ content is $66.1 \mathrm{~mol} \%$. The type strain is LMG 8670 (= ICMP 8682).

Description of Xanthomonas pisi (ex Goto and Okabe 1958) sp. nov., nom. rev. The description of $X$. pisi is the same as that of the genus. Isolated from diseased Pisum sativum (Fabaceae).

$X$. pisi has a distinct SDS-PAGE protein profile (48). It can be distinguished from other Xanthomonas species by the presence of metabolic activity on the carbon substrates dextrin glycogen, Tween 40 , Tween $80, \mathrm{~N}$-acetyl-D-galactosamine, $\mathrm{N}$ acetyl-D-glucosamine, L-arabinose, cellobiose, L-fucose, D-galactose, gentiobiose, $\alpha$-D-lactose, lactulose, maltose, D-mannitol, D-melibiose, $\beta$-methyl-D-glucoside, D-psicose, D-raffinose, L-rhamnose, D-sorbitol, sucrose, D-trehalose, turanose, monomethylsuccinate, cis-aconitic acid, citric acid, formic acid, D-galactonic acid lactone, D-galacturonic acid, D-gluconic acid, D-glucuronic acid, $\alpha$-hydroxybutyric acid, $p$-hydroxyphenylacetic acid, $\alpha$-ketobutyric acid, DL-lactic acid, malonic acid, propionic acid, D-saccharic acid, succinic acid, bromosuccinic acid, succinamic acid, glucuronamide, alaninamide, D-alanine, L-alanine, L-alanylglycine, L-asparagine, L-aspartic acid, L-glutamic acid, glycyl-L-aspartic acid, glycyl-L-glutamic acid, L-histidine, L-phenylalanine, L-proline, L-serine, L-threonine, urocanic acid, inosine, uridine, thymidine, glycerol, DL- $\alpha$-glycerolphosphate, glucose 1-phosphate, and glucose 6-phosphate and by a lack of metabolic activity on the carbon substrates acetic acid, $\beta$-hydroxybutyric acid, and $\alpha$-ketovaleric acid.

The $\mathrm{G}+\mathrm{C}$ content is $64.6 \mathrm{~mol} \%$. The type strain is LMG 847 $(=$ NCPPB $762=$ ICMP 570).

Description of Xanthomonas sacchari sp. nov. Xanthomonas sacchari (sac' cha.ri. L. masc. gen. n., sacchari, from sugar). The description of $X$. sacchari is the same as that of the genus. The strains of this species are isolated from diseased sugarcane (Saccharum officinarum).

$X$ sacchari strains have very distinct SDS-PAGE protein and FAME profiles $(51,60)$ and can be distinguished from other Xanthomonas species by the presence of metabolic activity on the carbon substrates dextrin, glycogen, Tween 40 , Tween 80 , $N$-acetyl-D-glucosamine, L-arabinose, cellobiose, L-fucose, Dgalactose, gentiobiose, $\alpha$-D-lactose, lactulose, maltose, $D$-melibiose, $\beta$-methyl-D-glucoside, D-psicose, sucrose, D-trehalose, turanose, monomethylsuccinate, acetic acid, cis-aconitic acid, citric acid, $\alpha$-hydroxybutyric acid, $\beta$-hydroxybutyric acid, $\alpha$-ketobutyric acid, $\alpha$-ketovaleric acid, DL-lactic acid, propionic acid, quinic acid, succinic acid, bromosuccinic acid, succinamic acid, alaninamide, D-alanine, L-alanine, L-alanylglycine, L-asparagine, L-aspartic acid, L-glutamic acid, glycyl-L-glutamic acid, hydroxy-L-proline, L-leucine, L-phenylalanine, L-serine, L-threonine, and glycerol and by a lack of metabolic activity on the carbon substrates $N$-acetyl-D-galactosamine, D-raffinose, Lrhamnose, D-sorbitol, $p$-hydroxyphenylacetic acid, malonic acid, glucuronamide, L-histidine, urocanic acid, thymidine, glucose 1-phosphate, and glucose-6-phosphate.

The $\mathrm{G}+\mathrm{C}$ content is $68.5 \mathrm{~mol} \%$. The type strain is LMG 471 .

Description of Xanthomonas theicola sp. nov. Xanthomonas theicola (the.i'co.la. L. fem. gen. n. theae, from tea; L. v. colere, to inhabit; L. adj. theicola, living in tea). The description of $X$. theicola is the same as that of the genus. The strains of this species cause disease in tea plants (Camellia sinensis).

$X$. theicola strains have very distinct SDS-PAGE protein and FAME profiles $(48,60)$ and can be distinguished from other Xanthomonas species by the presence of metabolic activity on the carbon substrates dextrin, glycogen, Tween 40 , Tween 80 , cellobiose, L-fucose, D-galactose, gentiobiose, maltose, D-psicose, $\beta$-hydroxybutyric acid, $\alpha$-ketovaleric acid, DL-lactic acid, alaninamide, D-alanine, L-alanine, L-alanylglycine, and hydroxy-L-proline and by a lack of metabolic activity on the carbon substrates $N$-acetyl-D-galactosamine, $N$-acetyl-D-glucosamine, $\alpha$-D-lactose, lactulose, D-mannitol, D-melibiose, $\beta$-methyl-D-glucoside, D-raffinose, sucrose, cis-aconitic acid, citric acid, formic acid, D-galactonic acid lactone, D-galacturonic acid, D-gluconic acid, D-glucuronic acid, $p$-hydroxyphenylacetic acid, $\alpha$-ketobutyric acid, malonic acid, propionic acid, 
quinic acid, D-saccharic acid, bromosuccinic acid, glucuronamide, L-asparagine, glycyl-L-aspartic acid, L-histidine, Lleucine, L-phenylalanine, urocanic acid, and thymidine.

The $\mathrm{G}+\mathrm{C}$ content is $69.2 \mathrm{~mol} \%$. The type strain is LMG 8684 (= ICMP 6774).

Description of Xanthomonas translucens (ex Jones, Johnson, and Reddy 1917) sp. nov., nom. rev. The description of $X$. translucens is the same as that of the genus. The strains of this species cause diseases in various members of the Poaceae. On the basis of phytopathogenic specialization or differences in virulence $(3,11)$, the following pathovars can be distinguished: $X$. translucens pv. arrhenatheri, $X$. translucens pv. cerealis, $X$. translucens pv. graminis, $X$. translucens pv. hordei, $X$. translucens pv. phlei, $X$. translucens pv. phleipratensis, $X$. translucens pv. poae, $X$. translucens pv. secalis, $X$. translucens pv. translucens, and $X$. translucens pv. undulosa.

$X$. translucens strains can be distinguished from other xanthomonads by their SDS-PAGE protein patterns and FAME profiles $(51,60)$, by the presence of metabolic activity on the carbon substrates dextrin, maltose, D-psicose, D-trehalose, alaninamide, L-alanylglycine, and L-glutamic acid, and by a lack of metabolic activity on the carbon substrates $N$-acetyl-D-galactosamine, $\alpha$-D-lactose, D-mannitol, D-melibiose, $\beta$-methylD-glucoside, D-raffinose, L-rhamnose, D-sorbitol, acetic acid, cis-aconitic acid, formic acid, D-galactonic acid lactone, D-galacturonic acid, D-gluconic acid, D-glucuronic acid, $p$-hydroxyphenylacetic acid, $\alpha$-ketobutyric acid, $\alpha$-ketovaleric acid, malonic acid, propionic acid, quinic acid, D-saccharic acid, glucuronamide, L-histidine, L-leucine, L-phenylalanine, L-proline, L-threonine, urocanic acid, inosine, thymidine, and DL- $\alpha$ glycerolphosphate.

The G+C content is 69.1 to $69.7 \mathrm{~mol} \%$. The type strain is $X$. translucens pv. translucens LMG $876(=$ NCPPB $973=$ ATCC 19319 = ICMP 5752).

Description of Xanthomonas vasicola sp. nov. Xanthomonas vasicola (vas.i'co.la. L. neut. n. vas, vascular bundle; L. v. colere, to inhabit; L. adj. vasicola, living in vascular bundles). The description of $X$. vasicola is the same as that of the genus. The following pathovars are distinguished on the basis of phytopathogenic specialization: $X$. vasicola pv. holcicola and $X$. vasicola pv. vasculorum. The latter pathovar includes the strains of the former taxon $X$. campestris pv. vasculorum type B.

The species can be clearly distinguished from other xanthomonads by its SDS-PAGE protein and FAME profiles (51, 60 ), by the presence of metabolic activity on the carbon substrates D-psicose and L-glutamic acid, and by a lack of metabolic activity on the carbon substrates $N$-acetyl-D-galactosamine, L-arabinose, $\alpha$-D-lactose, D-melibiose, $\beta$-methyl-Dglucoside, L-rhamnose, D-sorbitol, formic acid, D-galactonic acid lactone, D-galacturonic acid, D-gluconic acid, D-glucuronic acid, $p$-hydroxyphenylacetic acid, $\alpha$-ketovaleric acid, quinic acid, glucuronamide, L-asparagine, L-histidine, L-phenylalanine, urocanic acid, inosine, uridine, thymidine, DL- $\alpha$-glycerolphosphate, glucose 1-phosphate, and glucose 6-phosphate.

The $\mathrm{G}+\mathrm{C}$ content is $64.2 \mathrm{~mol} \%$. The type strain is $X$. vasicola pv. holcicola LMG $736(=$ NCPPB $2417=$ ICMP $3103=$ CFBP 2543).

Description of Xanthomonas vesicatoria (ex Doidge 1920) sp. nov., nom. rev. $X$. vesicatoria includes the strains of the former taxon $X$. campestris pv. vesicatoria type B. The description of $X$. vesicatoria is the same as that of the genus. The strains are isolated from diseased pepper plants (Capsicum spp.) and tomato plants (Lycopersicon spp.), as well as a number of other, mainly solanaceous hosts.

The species can be distinguished from other xanthomonads on the basis of its SDS-PAGE protein patterns (48), by the presence of metabolic activity on the carbon substrates dextrin, Tween 80, L-fucose, gentiobiose, maltose, D-psicose, D-trehalose, monomethylsuccinate, succinic acid, bromosuccinic acid, succinamic acid, alaninamide, L-alanine, L-glutamic acid, and $\mathrm{L}$-serine, and by a lack of metabolic activity on the carbon substrates L-arabinose, D-galactose, $\alpha$-D-lactose, $\beta$-methyl-Dglucoside, D-raffinose, $c i s$-aconitic acid, formic acid, D-galactonic acid lactone, D-gluconic acid, D-glucuronic acid, $p$-hydroxyphenylacetic acid, $\alpha$-ketovaleric acid, quinic acid, glucuronamide, glycyl-L-aspartic acid, thymidine, and glucose 6-phosphate.

The $\mathrm{G}+\mathrm{C}$ content is $65.6 \mathrm{~mol} \%$. The type strain is LMG 911 $(=$ NCPPB 422 = ICMP 63).

Xanthomonas sp. A total of 66 former $X$. campestris pathovars have not been placed in any Xanthomonas species yet. These include pathovars alangii, amaranthicola, amorphophalli, aracearum, arecae, argemones, arracaciae, azadirachtae, badrii, betae, bilvae, blepharidis, boerhaaviae, brunneivaginae, cannabis, cannae, carissae, centellae, clerodendri, convolvuli, coriandri, daturae, durantae, esculenti, eucalypti, euphorbiae, fici, guizotiae, gummisudans, heliotropii, ionidii, lantanae, laureliae, lawsoniae, leeana, leersiae, mangiferaeindicae, merremiae, mirabilis, musacearum, nigromaculans, olitorii, papavericola, passiflorae, paulliniae, pennamericanum, phormiicola, physalidis, plantaginis, sesami, spermacoces, syngonii, tardicrescens, thespesiae, thirumalacharii, tribuli, trichodesmae, uppalii, vernoniae, viticola, vitiscarnosae, vitistrifoliae, vitiswoodrowii, zantedeschiae, zingibericola, and zinniae.

Although protein and FAME profiles of almost all of these pathovars have been determined, it would be premature to classify them in the current species on the basis of these data alone. Rather than maintaining them as pathovars of $X$. campestris, we propose that they should be considered Xanthomonas sp. until they are properly allocated in the new Xanthomonas classification. In order to preserve the pathovar designations which they currently have, plant pathologists might use a nomenclature such as Xanthomonas sp. followed by the appropriate pathovar epithet.

\section{ACKNOWLEDGMENTS}

L.V. is indebted to the Nationaal Fonds voor Wetenschappelijk Onderzoek for a scholarship. K.K. acknowledges the Fonds voor Geneeskundig Wetenschappelijk Onderzoek for personnel and research grants.

\section{REFERENCES}

1. Andrewes, A. G., C. L. Jenkins, M. P. Starr, J. Shepherd, and H. Hope. 1976 Structure of xanthomonadin I, a novel dibrominated arylpolyene pigment produced by the bacterium Xanthomonas juglandis. Tetrahedron Lett. 45: 4023-4024.

2. Auling, G., H.-J. Busse, F. Pilz, L. Webb, H. Kneifel, and D. Claus. 1991 Rapid differentiation, by polyamine analysis, of Xanthomonas strains from phytopathogenic pseudomonads and other members of the class Proteobacteria interacting with plants. Int. J. Syst. Bacteriol. 41:223-228.

3. Azad, H., and N. W. Schaad. 1988. The relationship of Xanthomonas campestris pv. translucens to frost and the effect of frost on black chaff development in wheat. Phytopathology 78:95-100.

4. Berthier, Y., V. Verdier, J.-L. Guesdon, D. Chevrier, J.-B. Denis, G. Decoux, and M. Lemattre. 1993. Characterization of Xanthomonas campestris pathovars by rRNA gene restriction patterns. Appl. Environ. Microbiol. 59:851859.

5. Bochner, B. 1989. Sleuthing out bacterial identities. Nature (London) 339: 157-158.

6. Bouzar, H., J. B. Jones, R. E. Stall, N. C. Hodge, G. V. Minsavage, A. A. Benedict, and A. M. Alvarez. 1994. Physiological, chemical, serological, and pathogenic analyses of a worldwide collection of Xanthomonas campestris pv. vesicatoria strains. Phytopathology 84:663-671.

7. Bradbury, J. F. 1984 . Genus II. Xanthomonas Dowson 1939, $187^{\mathrm{AL}}$, p. 199-210. In N. R. Krieg and J. G. Holt (ed.), Bergey's manual of systematic bacteriology, vol. 1. Williams \& Wilkins, Baltimore.

8. Bradbury, J. F. 1986. Xanthomonas Dowson 1939, 187, p. 198-260. In Guide 
to plant pathogenic bacteria. $\mathrm{CAB}$ International Mycological Institute, Slough, United Kingdom.

9. Bryan, M. K. 1926. Bacterial leafspot on hübbard squash. Science 63:165.

10. Colwell, R. R., and J. Liston. 1961. Taxonomic analysis with the electronic computer of some Xanthomonas and Pseudomonas species. J. Bacteriol. 82:913-919.

11. Cunfer, B. M., and B. L. Scolari. 1982. Xanthomonas campestris pv. translucens on triticale and other small grains. Phytopathology 72:683-686.

12. De Ley, J. 1970. Reexamination of the association between melting point, buoyant density, and chemical base composition of deoxyribonucleic acid. J. Bacteriol. 101:738-754.

13. De Ley, J., H. Cattoir, and A. Reynaerts. 1970. The quantitative measurement of DNA hybridization from renaturation rates. Eur. J. Biochem. 12: 133-142.

14. De Vos, P., and J. De Ley. 1983. Intra- and intergeneric similarities of Pseudomonas and Xanthomonas ribosomal ribonucleic acid cistrons. Int. J. Syst. Bacteriol. 33:487-509.

15. Doidge, E. M. 1920. A tomato cancer. J. Dep. Agric. Union S. Afr. 1:718-721.

16. Dowson, W. J. 1939. On the systematic position and generic names of the Gram negative bacterial plant pathogens. Zentralbl. Bakteriol. Parasitenkd. Infektionskr. Hyg. Abt. 2 100:177-193.

17. Dye, D. W. 1962. The inadequacy of the usual determinative tests for the identification of Xanthomonas spp. N. Z, J. Sci. 5:393-416.

18. Dye, D. W., J. F. Bradbury, M. Goto, A. C. Hayward, R. A. Lelliott, and M. N. Schroth. 1980. International standards for naming pathovars of phytopathogenic bacteria and a list of pathovar names and pathotype strains. Rev. Plant Pathol. 59:153-168.

19. Dye, D. W., and R. A. Lelliott. 1974. Genus II. Xanthomonas, p. 243-249. In R. E. Buchanan and N. E. Gibbons (ed.), Bergey's manual of determinative bacteriology, 8th ed. Williams \& Wilkins, Baltimore.

20. Egel, D. S., J. H. Graham, and R. E. Stall. 1991. Genomic relatedness of Xanthomonas campestris strains causing diseases of citrus. Appl. Environ. Microbiol. 57:2724-2730.

21. Gabriel, D. W., J. E. Hunter, M. T. Kingsley, J. W. Miller, and G. R. Lazo. 1988. Clonal population structure of Xanthomonas campestris and genetic diversity among citrus canker strains. Mol. Plant Microbe Interact. 1:5965 .

22. Gabriel, D. W., M. T. Kingsley, J. E. Hunter, and T. Gottwald. 1989. Reinstatement of Xanthomonas citri (ex Hasse) and X. phaseoli (ex Smith) to species and reclassification of all $X$. campestris pv. citri strains. Int. J. Syst. Bacteriol. 39:14-22

23. Goto, M., and N. Okabe. 1958. Bacterial plant diseases in Japan. IX. 1. Bacterial stem rot of pea. 2. Halo blight of bean. 3. Bacterial spot of physalis plant. Rep. Fac. Agric. Shizuoka Univ. 8:33-49.

24. Hartung, J. S., and E. L. Civerolo. 1987. Genomic fingerprints of Xanthomonas campestris pv. citri strains from Asia, South America, and Florida. Phytopathology 77:282-285.

25. Hartung, J. S., and E. L. Civerolo. 1989. Restriction fragment length polymorphisms distinguish Xanthomonas campestris strains isolated from Florida citrus nurseries from $X$. c. pv. citri. Phytopathology 79:793-799.

26. Hayward, A. C. 1993. The hosts of Xanthomonas, p. 1-119. In J. G. Swings and E. L. Civerolo (ed.), Xanthomonas. Chapman \& Hall, London.

27. Hildebrand, D. C., M. Hendson, and M. N. Schroth. 1993. Usefulness of nutritional screening for the identification of Xanthomonas campestris DNA homology groups and pathovars. J. Appl. Bacteriol. 75:447-455.

28. Hildebrand, D. C., N. J. Palleroni, and M. N. Schroth. 1990. Deoxyribonucleic acid relatedness of 24 xanthomonad strains representing 23 Xanthomonas campestris pathovars and Xánthomonas fragariae. J. Appl. Bacteriol. 68:263-269.

29. Johnson, J. L. 1984. Nucleic acids in bacterial classification, p. 8-11. In N. R. Krieg and J. G. Holt (ed.), Bergey's manual of systematic bacteriology, vol. 1. Williams \& Wilkins, Baltimore

30. Jones, J. B., A. R. Chase, and G. K. Harris. 1993. Evaluation of the Biolog GN MicroPlate system for identification of some plant-pathogenic bacteria. Plant Dis. 77:553-558.

31. Jones, L. R., A. G. Johnson, and C. S. Reddy. 1917. Bacterial blight of barley J. Agric. Res. 11:625-644.

31a.Lapage, S. P., P. H. A. Sneath, E. F. Lessel, V. B. D. Skerman, H. P. R. Seeliger, and W. A. Clark (ed.). 1975. International code of nomenclature of bacteria. 1976 Revision. American Society for Microbiology, Washington, D.C.

32. Lazo, G. R., R. Roffey, and D. W. Gabriel. 1987. Pathovars of Xanthomonas campestris are distinguishable by restriction fragment length polymorphism. Int. J. Syst. Bacteriol. 37:214-221.

33. Lee, Y.-A., D. C. Hildebrand, and M. N. Schroth. 1992. Use of quinate metabolism as a phenotypic property to identify members of Xanthomonas campestris DNA homology group 6. Phytopathology 82:971-973.

34. Marmur, J. 1961. A procedure for the isolation of deoxyribonucleic acid from microorganisms. J. Mol. Biol. 3:208-218.

35. Murata, G. R., and M. P. Starr. 1973. A concept of the genus Xanthomonas and its species in the light of segmental homology of deoxyribonucleic acids. Phytopathol. Z. 77:285-323.
36. Palleroni, N. J. and J. F. Bradbury. 1993. Stenotrophomonas, a new bacterial genus for Xanthomonas maltophilia (Hugh 1980) Swings et al. 1983. Int. J. Syst. Bacteriol. 43:606-609.

37. Palleroni, N. J. D. C. Hildebrand, M. N. Schroth, and M. Hendson. 1993. Deoxyribonucleic acid relatedness of 21 strains of Xanthomonas species and pathovars. J. Appl. Bacteriol. 75:441-446.

38. Schleifer, K. H., and E. Stackebrandt. 1983. Molecular systematics of prokaryotes. Annu. Rev. Microbiol. 37:143-187.

39. Schroth, M. N., and O. C. Hildebrand. 1983. Towards a sensible taxonomy of bacterial plant pathogens. Plant Dis. 67:128.

40. Stall, R. E., C. Beaulieu, D. Egel, N. C. Hodge, R. P. Leite, G. V. Minsavage, H. Bouzar, J. B. Jones, A. M. Alvarez, and A. A. Benedict. 1994. Two genetically diverse groups of strains are included in Xanthomonas campestris pv, vesicatoria. Int. J. Syst. Bacteriol. 44:47-53.

41. Starr, M. P., and O. C. Garcés. 1950. El agente causante de la gomosis bacterial del pasto imperial en Colombia. Rev. Fac. Nac. Agron. Medellin 12:73-83.

42. Swings, J., P. De Vos, M. Van den Mooter, and J. De Ley. 1983. Transfer of Pseudomonas maltophilia Hugh 1981 to the genus Xanthomonas as Xanthomonas maltophilia (Hugh 1981) comb. nov. Int. J. Syst. Bacteriol. 33:409413.

43. Swings, J., M. Van den Mooter, L. Vauterin, B. Hoste, M. Gillis, T. W. Mew, and K. Kersters. 1991. Reclassification of the causal agents of bacterial blight (Xanthomonas campestris pv. oryzae) and bacterial leaf streak (Xanthomonas campestris pv. oryzicola) of rice as pathovars of Xanthomonas oryzae (ex Ishiyama 1922) sp. nov., nom. rev. Int. J. Syst. Bacteriol. 40:301311 .

44. Van den Mooter, M., H. Maraite, L. Meiresonne, J. Swings, M. Gillis, K. Kersters, and J. De Ley. 1987. Comparison between Xanthomonas campestris pv. manihotis (ISPP List 1980) and $X$. campestris pv. cassavae (ISPP List 1980) by means of phenotypic, protein electrophoretic, DNA hybridization and phytopathological techniques. J. Gen. Microbiol. 133:57-71.

45. Van den Mooter, M., M. Steenackers, C. Maertens, F. Gosselé, P. De Vos, J. Swings, K. Kersters, and J. De Ley. 1987. Differentiation between Xanthomonas campestris pv. graminis (ISPP List 1980), pv. phleipratensis (ISPP List 1980) emend., pv. poae Egli and Schmidt 1982 and pv. arrhenatheri Egli and Schmidt 1982 by numerical analysis of phenotypic features and protein gel electrophoregrams. J. Phytopathol. 118:135-156.

46. Van den Mooter, M., and J. Swings. 1990. Numerical analysis of 295 phenotypic features of 266 Xanthomonas strains and related strains and an improved taxonomy of the genus. Int. J. Syst. Bacteriol. 40:348-369.

46a.Vauterin, L. Unpublished data.

47. Vauterin, L., B. Hoste, P. Yang, A. Alvarez, K. Kersters, and J. Swings. 1993. Taxonomy of the genus Xanthomonas, p. 157-192. In J. G. Swings and E. L. Civerolo (ed.), Xanthomonas. Chapman \& Hall, London.

48. Vauterin, L., J. Swings, and K. Kersters. 1991. Grouping of Xanthomonas campestris pathovars by SDS-PAGE of proteins. J. Gen. Microbiol. 137: 1677-1687.

49. Vauterin, L., J. Swings, K. Kersters, M. Gillis, T. W. Mew, M. N. Schroth, N. J. Palleroni, D. C. Hildebrand, D. E. Stead, E. L. Civerolo, A. C. Hayward, H. Maraite, R. E. Stall, A. K. Vidaver, and J. F. Bradbury. 1990. Towards an improved taxonomy of Xanthomonas. Int. J. Syst. Bacteriol. 40:312-316.

50. Vauterin, L., R. Vantomme, B. Pot, B. Hoste, J. Swings, and K. Kersters. 1990. Taxonomic analysis of Xanthomonas campestris pv. begoniae and $X$. campestris pv. pelargonii by means of phytopathological, phenotypic, protein electrophoretic and DNA hybridization methods. Syst. Appl. Microbiol. 13: 166-176.

50a.Vauterin, L., and J. Van Vaerenbergh. Unpublished data

51. Vauterin, L., P. Yang, B. Hoste, B. Pot, J. Swings, and K. Kersters. 1992. Taxonomy of xanthomonads from cereals and grasses based on SDS-PAGE of proteins, fatty acid analysis and DNA hybridization. J. Gen. Microbiol. 138:1467-1477.

52. Vauterin, L., P. Yang, B. Hoste, M. Vancanneyt, E. L. Civerolo, J. Swings, and K. Kersters. 1991. Differentiation of Xanthomonas campestris pv. citri strains by sodium dodecyl sulfate-polyacrylamide gel electrophoresis of proteins, fatty acid analysis, and DNA hybridization. Int. J. Syst. Bacteriol. 41:535-542.

53. Vera Cruz, C. M., F. Gosselé, K. Kersters, P. Segers, M. Van den Mooter, J. Swings, and J. De Ley. 1984. Differentiation between Xanthomonas campestris pv. oryzae, $X$. campestris pv. oryzicola and the 'brown blotch' pathogen on rice by numerical analysis of phenotypic features and protein gel electrophoregrams. J. Gen. Microbiol. 130:2983-2999.

54. Verniere, C., O. Pruvost, E. L. Civerolo, O. Gambin, J. P. JacquemoudCollet, and J. Luisetti. 1993. Evaluation of the Biolog substrate utilization system to identify and assess metabolic variation among strains of Xanthomonas campestris pv. citri. Appl. Environ. Microbiol. 59:243-249.

55. Wakker, J. H. 1883. Vorläufige Mitteilungen über Hyacinthenkrankheiten. Bot. Centralbl. 14:315-317.

56. Wayne, L. G., D. J. Brenner, R. R. Colwell, P. A. D. Grimont, O. Kandler, M. I. Krichersky, L. H. Moore, W. E. C. Moore, R. G. E. Murray, E. Stackebrandt, M. P. Starr, and H. G. Trüper. 1987. Report of the Ad Hoc Committee on Reconciliation of Approaches to Bacterial System- 
atics. Int. J. Syst. Bacteriol. 37:463-464.

57. Wiehe, P. O., and W. J. Dowson. 1953. A bacterial disease of cassava (Manihot utilissima) in Nyasaland. Emp. J. Exp. Agric. 21:141-143.

58. Yang, P., P. De Vos, K. Kersters, and J. Swings. 1993. Polyamine patterns as chemotaxonomic markers for the genus Xanthomonas. Int. J. Syst. Bacteriol. 43:709-714.
59. Yang, P., P. Rott, L. Vauterin, B. Hoste, P. Baudin, K. Kersters, and J. Swings. 1993. Intraspecific variability of Xanthomonas albilineans. Syst. Appl. Microbiol. 16:420-426.

60. Yang, P., L. Vauterin, M. Vancanneyt, J. Swings, and K. Kersters. 1993. Application of fatty acid methyl esters for the taxonomic analysis of the genus Xanthomonas. Syst. Appl. Microbiol. 16:47-71. 